EPOS, XVII (2001), págs. 413-456

\title{
PUBLICACIONES SOBRE FILOLOGÍA GRIEGA EN ESPAÑA (2000)
}

HELENa RodRfGuez Somolinos

UNED. Madrid

\section{ORGANIZACIÓN}

1. Actas de congresos. Homenajes. Volúmenes colectivos

2. AUtORES ANTIGUOS. EDICIONES, TRADUCCIONES Y ESTUDIOS

3. Historia DE LA LITERATURA

4. LingứSTICA GRIEGA. MÉtrica

5. Micenología

6. EPIGRAFIA

7. Historia de LOS TEXTOS

8. Historia. Cultura. Sociedad

9. ReLigión. Mitología

10. CRISTIANISMo PRIMITIVO

11. Filosofia. Ciencia

12. Pervivencia. Humanismo. Historia de la filología

13. Diccionarios. Repertorios. Otros INSTRUMENTOS

14. DidÁCTICA 
REVISTAS

AEF : $\quad$ Anuario de Estudios Filológicos. Cáceres. Universidad de Extremadura. Facultad de Filosofía y Letras.

AF-SGL Anuari de Filologia. Secció D. Studia Graeca et Latina. Universitat de Barcelona. Facultat de Filologia.

AM: Analecta Malacitana. Universidad de Málaga. Facultad de Filosofía y Letras. Sección de Filología.

AuOr: Aula Orientalis. Revista de Estudios del Próximo Oriente Antiguo. Sabadell (Barcelona). Editorial Ausa.

Cal.Ren. Calamus Renascens. Revista de Humanismo y tradición clásica. Alcañiz - Cádiz, Instituto de Estudios Humanísticos, Instituto de Estudios Turolenses, Universidad de Cádiz.

Capsa: Capsa. Revista de didáctica de lenguas y cultura clásicas. Madrid, Ediciones Clásicas.

CFCG: Cuadernos de Filología Clásica. Estudios Griegos e Indoeuropeos. Universidad Complutense de Madrid. Facultad de Filología.

CFCL: $\quad$ Cuadernos de Filología Clásica. Estudios Latinos. Universidad Complutense de Madrid. Facultad de Filología.

EB: $\quad$ Estudios Bíblicos. Madrid. C.S.I.C. Patronato Menéndez Pelayo. Instituto Francisco Suárez.

EClás.: Estudios Clásicos. Madrid, Sociedad Española de Estudios Clásicos.

Emerita: Emerita. Revista de Lingüística y Filología Clásica. Madrid, C.S.I.C., Instituto de Filología.

Epos: $\quad$ Epos. Revista de Filología. Madrid. Universidad Nacional de Educación a Distancia. Facultad de Filología.

Exc.Phil:: Excerpta Philologica. Revista de Filología Griega y Latina. Universidad de Cádiz.

Faventia: Faventia. Universitat Autònoma de Barcelona. Facultat de Lletres. Dpto. de Filología Clásica.

FN: $\quad$ Filología Neotestamentaria. Universidad de Córdoba. Facultad de Filosofía y Letras.

FI: Florentia lliberritana. Revista de Estudios de Antigüedad Clásica. Universidad de Granada.

Fortunatae: Fortunatae. Revista canaria de filología, cultura y humanidades clásicas. Universidad de la Laguna. Dpto. de Filología Clásica y Arabe.

Gerión: Gerión. Universidad Complutense de Madrid. Dpto. de Historia Antigua.

Habis: $\quad$ Habis. Universidad de Sevilla.

HAnt.: Hispania Antiqua. Revista de Historia Antigua. Universidad de Valladolid. Departamento de Historia Antigua. 
Helmantica: Helmantica. Revista de Filología Clásica y Hebrea. Universidad Pontificia de Salamanca.

Iberia: Iberia. Revista de la Antigüedad. Universidad de La Rioja.

'Ilu: 'Ilu. Revista de Ciencias de las Religiones. Universidad Complutense de Madrid. Instituto Universitario de Ciencias de las Religiones.

İtaca: Ítaca. Quaderns Catalans de Cultura Clàsica. Barcelona. Instituto de Estudios Catalanes.

MHA: Memorias de Historia Antigua. Universidad de Oviedo. Instituto de Historia Antigua.

Minerva Minerva. Revista de Filología Clásica. Universidad de Valladolid. Dpto. de Filología Clásica.

Minos: Minos. Revista de Filología Egea. Universidad de Salamanca y Universidad del País Vasco.

Myrtia: Myrtia. Universidad de Murcia.

Perficit: Perficit. Publicación de Estudios Clásicos. Textos y Estudios. Salamanca.

Polis: $\quad$ Polis. Revista de ideas y formas políticas de la Antiguiedad Clásica. Universidad de Alcalá de Henares.

R.S.E.L.: Revista Española de Lingǘstica. Organo de la Sociedad Española de Lingüística. Madrid, Editorial Gredos.

SPhV: $\quad$ Studia Philologica Valentina. Universidad de Valencia.

Tempus Tempus. Revista de actualización científica. Madrid. Ediciones Clásicas.

Veleia: Veleia. Revista de Prehistoria, Historia Antigua, Arqueología y Filología Clásica. Vitoria. Universidad del País Vasco. Instituto de Ciencias de la Antigüedad.

Zephyrus Zephyrus. Revista de Prehistoria e Historia Antigua. Universidad de Salamanca.

1. ACtAs de CONGRESOS. HomenaJes. Volúmenes COlectivos

Alganza Roldán, M.; Camacho Rojo, J.M.; Fuentes González, J.M.; VRlena

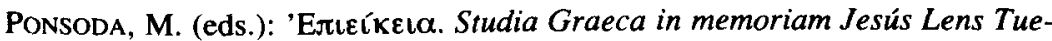

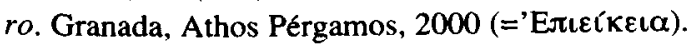

Alvar, J.; BlÁzQUez, J.M. (eds.): Alejandro Magno. Hombre y mito. Madrid, Actas, 2000 (= Alejandro Magno).

Bécares, V.; Pordomingo, F.; Cortés Tovar, R.; Fernández Corte, J.C. (eds.): Intertextualidad en las literaturas griega y latina. Madrid, Ediciones Clásicas, 2000 (= Intertextualidad).

BoWman, A.K.; WoOLF, G. (eds.): Cultura escrita y poder en el mundo antiguo. Traducción de A. Bixio. Barcelona, Gedisa, 2000 (= Cultura escrita y poder). 
Branham, R.B.; Goulet.CAZE, M.-O. (eds.): Los cínicos. El movimiento cínico en la antigüedad y su legado. Barcelona, Seix Barral, 2000 (= Los cínicos).

Brioso Sánchez, M.; Villarrubia Medina, A.: Consideraciones en torno al amor en la literatura de la Grecia Antigua. Sevilla, Universidad, 2000 (=Consideraciones en torno al amor).

CABRERa Bonet, P.; SÁnchez Fernandez, C.: Los griegos en España. Tras las huellas de Heracles. Catálogo de la exposición. Madrid, Ministerio de Educación y cultura, 2000 (= Los griegos en España).

CASTRILlo BentTo, $N$. (ed.): La herencia greco-latina en la lengua y literatura castellanas. Actas de las XII Jornadas de Filología Clásica de Castilla y León (Burgos, 1998). Burgos, Universidad, $2000(=$ La herencia greco-latina).

Cortés Gabaudán, F.; Hinojo Andrés, G.; López Eire, A. (eds.): Retórica, política $e$ ideología. Desde la Antigüedad a nuestros días. Actas del II Congreso Internacional (Salamanca, Noviembre de 1997), Volumen III. Ponencias. Salamanca, Logo; Asociación Española de Estudios sobre Lengua, Pensamiento y Cultura Clásica, 2000 (= Retórica, politica e ideología).

Crespo, E.; Barrios, M.J. (eds.): Actas del X Congreso Español de Estudios Clási$\cos$ (21-25 de Septiembre de 1999. Volumen I. Sesiones de inauguración y clausura. Lingüística griega. Literatura griega. Madrid, Sociedad Española de Estudios Clásicos, 2000 (= Actas del X Congreso I).

Cristóbal, V.; LOPEZ de Juan, C. (eds.): Feliz quien como Ulises. Viajes en la Antigüedad. Madrid, Ediciones Clásicas; Sociedad Española de Estudios Clásicos, 2000 (= Feliz quien como Ulises)

DuboIs, L.; MAsson, E. (eds.): Philokypros. Mélanges de Philologie et d'Antiquités grecques et proche-orientales dédiés à la mémoire d'Olivier Masson. Suplementos a Minos n. ${ }^{\circ}$ 16. Salamanca, Universidad, 2000 (= Philokypros).

GÉNERO, DOMINACIÓN Y CONFLICTO: LA MUJER EN EL MUNDO ANTIGUO. Studia Historica; Historia Antigua 18. Salamanca, Universidad, 2000 (= Género, dominación y conflicto).

LURI MedRANo, G. (ed.): La razón del mito. I Congreso de Mitología Mediterránea (Terrassa, 1-3 de Julio de 1998). Madrid, Universidad Nacional de Educación a Distancia, 2000 (= La razón del mito).

Marcos Casquero, M.A. (ed.): Creencias y supersticiones en el mundo clásico y medieval. XIV Jornadas de Estudios Clásicos de Castilla y León. León, Universidad, 2000 ( $=$ Creencias y supersticiones).

MÁrquez Guerrero, M.Á.; RAMíreZ DE Verger, A.; Zambrano, P. (eds.): El retrato literario. Tempestades y naufragios. Escritura y reelaboración. Actas del XII Simposio de la Sociedad Española de Literatura General y Comparada. Huelva, Universidad, 2000 (=El retrato literario).

MARTINEZ HERNÁNDEZ, M. et alii (eds.): Cien años de investigación semántica: de Michel Bréal a la actualidad. Actas del Congreso Internacional de Semánti- 
ca (Universidad de La Laguna, 27-3I de Octubre de 1997) I y II. Madrid, Ediciones Clásicas, 2000 (= Actas del Congreso Internacional de Semántica $I$ y $I I)$.

MASCARó, J. et alii: Aspectos didácticos de lenguas clásicas I. Zaragoza, Universidad, 2000 (= Aspectos didácticos).

Myro, M.M.; Casillas, J.M.; Alvar, J.; Plácido, D. (eds.): Las edades de la dependencia durante la Antigüedad. Madrid, Ediciones Clásicas, 2000 (= Las edades de la dependencia).

Pérez Jiménez, A.; Cruz Andreotti, G. (eds.): Dieta mediterránea. Comidas y hábitos alimenticios en las culturas mediterráneas. Madrid, Ediciones Clásicas, 2000 (= Dieta mediterránea).

2. Autores antiguos. Ediciones, traducciónes y estudios

\section{Acusilaus}

Merino Martinez, J.I.: «La racionalización del mito en Acusilao, Hecateo y Helánico»; Actas del X Congreso I, 527-532.

\section{Aeschines}

EsQuines: Discursos. Cartas. Introducción, traducción y notas de J.M. García Ruiz. Madrid, Ediciones Clásicas, 2000.

\section{Aeschylus}

Bañuls Oller, J.V.: «Esquilo, Persas 28», Actas del X Congreso I, 329-334.

Esoullo: Las coéforas. Versión de F. Expósito Sánchez y F. Palencia Cortés. Madrid, Ediciones Clásicas, 2000.

EsquILo - EURIPIDES: Prometeo encadenado. Los persas. Medea. Barcelona, Océano, 2000.

Gallego, J.: «Figuras de la tiranía, lo femenino y lo masculino en la Orestía de Esquilo», Género, dominación y conflicto 65-90.

PéreZ MARTEl, J.M.: «Semántica y hermenéutica en los escolios y glosas de las tragedias de Esquilo", Actas del Congreso Internacional de Semántica II, 11611174.

VEGA VEGA, M.M.: «Casandra y su vocabulario mágico en Homero y Esquilo», Actas del X Congreso I, 657-663. 


\section{Aesopus et Aesopica}

Gómez CaRdó, P.: «Los animales también ríen», Actas del X Congreso I, 431-438.

\section{Alciphro}

Calero SeCall, I.: «Las relaciones familiares en las cartas de Alcifrón», Actas del X Congreso I, 343-350.

\section{Anacharsis}

MARTIN, R.P.: «El acento escita: Anacarsis y los cínicos», Los cínicos 182-207.

\section{Andocides}

IGLESIAS ZOIDO, J.C.: «El ejemplo histórico en Andócides», AEF 23, 2000, 229-242.

\section{Anthologia Graeca}

Giangrande, G.: «Asclepiades and Prostitution», Myrtia 15, 2000, 255-258.

GuICHARD, L.A.: «Intertextualidad y antologación en la Corona de Meleagro», Intertextualidad 105-119.

Ortega Villaro, B.: «Epigramas de la Antología Griega relativos a la magia y a la superstición», Creencias y supersticiones 189-200.

WhITE, H.: «Two epigrams on Hipponax», Myrtia 15, 2000, 259-263.

\section{Apollodorus mythographus}

TORnÉ TeIXIDÓ, R.: «Aportación al texto de la Biblioteca mitológica del PseudoApolodoro (III 1.1 [2-4])», AF-SGL 21, 1998/99, 143-147.

\section{Apollonius Rhodius}

PÉREZ LOPEZ, M.: «Od.6.-273-315 y A.R.3.771-801: un ejemplo de intertextualidad», Actas del X Congreso 1, 581-588. 


\section{Aratus}

Pereiro Pardo, A.: «Estudio léxico de los verbos que expresan el orto de los astros en los Fenómenos de Arato», Actas del X Congresa I, 227-233.

\section{Archilochus}

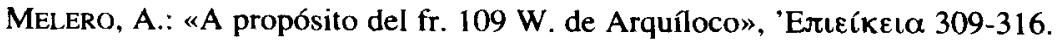

PORTULAS, J.: «Archilochea», Intertextualidad 33-39.

\section{Aristides}

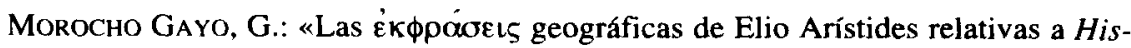

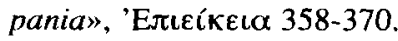

\section{Aristo Chius}

PORTER, J.I.: «La filosofía de Aristón de Quíos», Los cínicos 208-250.

\section{Aristophanes}

Amado Rodriguez, M.T.: «Los cómicos y el nuevo ditirambo (Ar.Av.1373-1409)», Actas del X Congreso I, 315-322.

ARISTÓfANES: La Pau. Traducció i pròleg de C. Carandell. Barcelona, Institut del Teatro de la Diputació de Barcelona, 2000.

Aristófanes: Lisístrata. Traducció i pròleg de C. Carandell. Barcelona, Institut del Teatro de la Diputació de Barcelona, 2000.

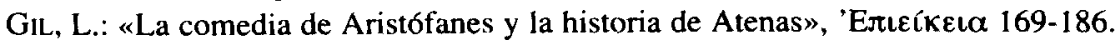
LABIANO ILUNDÁIN, J.M.: Estudio de las interjecciones en las comedias de Aristófanes. Amsterdam-Las Palmas, Hakkert, 2000.

LÓPEZ EIRE, A.: «Reflexiones sobre la comedia aristofánica», Myrtia 15, 2000, 69102.

Macía AParicio, L.M.: «Parodias de situaciones y versos homéricos en Aristófanes», Emerita 68, 2000, 211-241.

Nava Contreras, M.: «Parodia y antiutopía en Las Aves de Aristófanes», Actas del $X$ Congreso I, 573-580.

TAillardat, J.: «Aristophane, Ecclesiazousae 148», Philokypros 293-297. 
Tzilılis, S.: «A propósito de la representación de Las Nubes», CFCG 10, 2000, 91104.

\section{Aristoteles}

ARISTÓTEles: Sobre las líneas indivisibles. Mecánica; EuCLIDEs: Óptica. Catóptrica. Fenómenos. Introducción, traducción y notas de P. Ortiz García. Madrid, Gredos, 2000. ARISTótEles: La constitución de Atenas. Edición bilingüe, traducción y estudio preliminar de A. Tovar. Madrid, Centro de estudios Constitucionales, 2000.

ARISTÓteles: Partes de los animales. Marcha de los animales. Movimiento de los animales. Introducción, traducción y notas de E. Jiménez Sánchez-Escariche y A. Alonso Miguel. Madrid, Gredos, 2000.

ARISTóteles: Ética. Traducción de J. Leyva Fernández. Madrid, Libsa, 2000.

ARISTóteles: Poética. Introducción, traducción y notas de S. Mas. Madrid, Biblioteca Nueva, 2000.

ARISTÓteles: Poética. Traducción al gallego de F. González Muños. La Coruña, Universidad, 2000.

Cortés GabaudÁN, F.: «La condena de los sentimientos en la Retórica aristotélica», Actas del X Congreso I, 363-370.

Giménez Pérez, F.: Physis, logos y polis. La filosofía política de Platón y Aristóteles. Madrid, F. Giménez-Pérez - Sociedad de Estudios de Filosofía Materialista, 2000.

NATALI, C.: «Responsabilità e determinismo nella retorica e nella filosofia prattica aristotelica», Retórica, política e ideología 141-157.

TOMÁs DE AQUINO, SANTO:In decem libros Ethicorum Aristotelis ad Nicomachum expositio. Comentario a la Ética a Nicómaco de Aristóteles. Traducción de A. Mallea. Estudio preliminar y notas de C.A. Lértora Mendoza. Pamplona, EUNSA, 2000.

UÑa JuÁreZ, A.: Así nació la filosofía. Sobre el texto de Aristóteles (Metafísica 1,3) en torno a Tales de Mileto. Madrid, A. Uña Juárez, 2000.

\section{Asclepiades epigrammaticus}

Giangrande, G.: «Asclepiades and Prostitution», Myrtia 15, 2000, 255-258.

\section{Athenaeus}

Pérez MARTel, J.M.: «Disquisiciones semánticas en Ateneo de Náucratis», Actas del $X$ Congreso I, 235-242. 


\section{Bacchylides}

GaRCía RAMÓN, J.L.: «Fraseología heredada e innovación en lengua de la lírica coral:

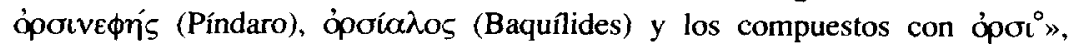

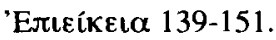

\section{Batrachomyomachia}

HIMNos homÉRICos. BATRAComiomaquia. Edición de M.A. García Velázquez. Madrid, Akal, 2000.

\section{Biblia Graeca}

BEGG, C.T.: «The retellings of the story of Judges 19 by Pseudo-Philo and Josephus: a comparison», $E B$ 58, 2000, 33-49.

BIGUZZI, G.: «Efesini: la misteriosa lettera del muro abbattuto», EB 58, 2000, 347 364.

DERRETT, J.D.M.: «An apt student's matriculation (Lk 2,39-52)», EB 58, 2000, 101122.

Diccionario Griego-español del Nuevo Testamento. Análisis semántico de los vocablos (DGENT). Fascículo 1 ('A $\alpha \rho \omega ́ v-\alpha \mu \alpha \tau \varepsilon \kappa \chi v \sigma i \alpha$ ). Dirigido por J. Mateos con la colaboración de J. Peláez y el Grupo de Análisis Semántico de la Universidad de Córdoba (GASCO). Córdoba, El Almendro, 2000.

GaRCíA. J.M.: «Acontecimientos después de la venida gloriosa», EB 58, 2000, 527-559.

Guijarro Oporto, S.: «La dimensión política de los exorcismos de Jesús», $E B$ 58, 2000, $51-77$.

HiLL, R.C.: «Theodoret's commentary on Paul», EB 58, 2000, 79-99.

HURLEY, R.: «TO marry or not to marry: the interpretation of 1Cor 7:36-38», EB 58, $2000,7-31$.

LÏFSTEDT, T.: «The allegory of Hagar and Sarah: Gal.4.21-31», EB 58, 2000, 475-494.

LÓPEZ PEGo, A.: «Evolución del significado de $\theta \dot{\varepsilon} \lambda \eta \mu \alpha$ voluntad del Antiguo al Nuevo Testamento», EB 58, 2000, 309-346.

Oden, T.C.; Hall, V.A. (EDS.): Evangelio según San Marcos. La Biblia comentada por los Padres de la Iglesia y otros autores de época patrística. Nuevo Testamento. Vol. II. Director de la edición en Castellano M. Merino Rodríguez. Madrid, Ciudad Nueva, 2000.

Pel.Aez del Rosal, J.: «Del lexema al lema. Pasos para la redacción de los lemas del Diccionario Griego-Español del Nuevo Testamento", Actas del Congreso Internacional de Semántica II, 1151-1159. 
RIUS CAMPS, J.: «El ciego de Betsaida/Betania (Mc 8,22-26)», EB 58, 2000, 289-308.

SÁNCHEZ NAVARRO, L.: «Mt 19,3-9: una nueva perspectiva», $E B$ 58, 2000, 211-238.

SMIT, J.F.M.: «You shall not muzzle a threshing ox. Paul's use of the law of Moses in 1Cor 9,8-12», EB 58, 2000, 239-263.

Vicent CeRnUdA, A.: «Pecado, conversión y gratitud de María de Betania», EB 58, 2000, 365-397.

\section{Charito}

Paglialunga, E.: «Amor y celos en los personajes masculinos de Caritón de Afrodisia», FI 11, 2000, 181-194.

\section{Corpus Hermeticum}

CORPUS HERMETICUM Y ASCLEPIO. Edición de B.P. Copenhaver. Madrid, Siruela, 2000.

\section{Crates Thebanus}

Long, A.A.: «Diógenes, Crates y la ética helenística», Los cínicos 45-68.

\section{Demades}

GaRzYA, A.: «Varia philologica XVII», 'Eлıєíkeıa 167-168.

\section{Demosthenes}

HERnÁNDEZ MuÑOZ, F.G.: «Notas al Matritensis núm. 4647: Constantino Láscaris y el texto de Demóstenes», CFCG 10, 2000, 253-266.

LÓPEZ EIRE, A.: «Sobre el estilo de Demóstenes», 'E

\section{Dio Chrysostomus}

Dión De Prusa: Discursos $L X I-L X X X$. Introducción, traducción y notas de G. del Cerro Calderón. Madrid, Gredos, 2000.

Giangrande, G.: «Sobre el texto de Dión Crisóstomo, ORatio XI», Myrtia 15, 2000, 247-253. 
Mestre Roca, F.: «¿Por qué miente Homero? (Una visión histórica de los poemas homéricos en época imperial», Actas del X Congreso I, 532-540.

\section{Diodorus Siculus}

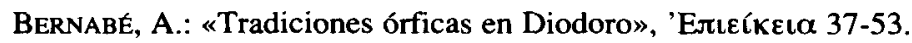

Chamoux, F.: «Les naufragés de la Mer Rouge (Diodore de Sicile III 40)»,

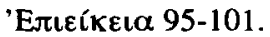

Hoz, J. DE: «La etnografía de los pueblos de Iberia en Diodoro V 33-34 y el problema de sus fuentes», 'Eлıєíkeı 2 21-238.

SPOERRI, W.: «À propos du Diodore d' Henri Estienne (Genève 1559): impressions

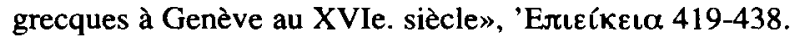

Xella, P.: «I Xpuooĩ vooí dei Cartaginesi», AuOr 17/18, 1999/2000, 363-366.

\section{Diogenes Sinopensis}

BRAChT BRANHAM, R.: «Invalidar la moneda en curso: la retórica de Diógenes y la invención del cinismo», Los cínicos 111-141.

Clay, D.: «Retratar a Diógenes», Los cínicos 475-499.

KRUEGER, D.: «El desvergonzado y la sociedad. La impudicia de Diógenes en la cultura romana imperial», Los cínicos 290-314.

LoNG, A.A.: «Diógenes, Crates y la ética helenística», Los cínicos 45-68.

NiEhUES-PRÖBSTING, H.: «La recepción moderna del cinismo: Diógenes y la Ilustración», Los cínicos 430-474.

\section{Epicurus}

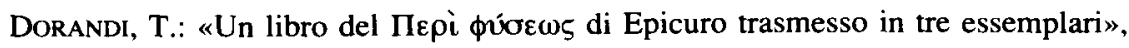

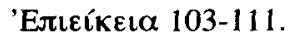

EpICURo: Sobre la felicidad. Prólogo de E. Lled6. Traducción de C. García Gual. Madrid, Debate, 2000.

Epimerismi Homerici

v. Homerus

\section{Euphorio}

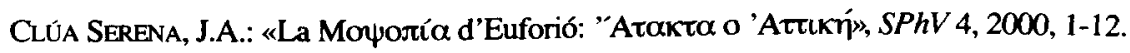




\section{Euripides}

BENAVENTE, M.: Una reiterada ambiguiedad en la Alcestis de Eurípides», FI 11, 2000, 11-19.

CONTI, L. JiMÉnEZ: «Perturbaciones mentales en los poemas homéricos y en las tragedias de Sófocles y Eurípides», Myrtia 15, 2000, 35-50.

Esquilo - EuRIPIDES: Prometeo encadenado. Los persas. Medea. Barcelona, Océano, 2000.

EURIPIDES: Tragedias III. Edición de J.M. Labiano. Madrid, Cátedra, 2000.

EURIPIDES: Tragedias IV: Electra, Orestes. Introducción, texto revisado y traducción de A. Guzmán Guerra. Madrid, Consejo Superior de Investigaciones Científicas, 2000.

EURfPIDES: As troianas. Trad. de M.H. da Rocha Pereira. Madrid, Ediciones Clásicas, 2000.

EURIPIDES: Andrómaca. Introdução e versão do grego de J. Ribeiro Ferreira. Madrid, Ediciones Clásicas, 2000.

EurfPIDEs: Medea, Electra. Prólogo de J. de la Cruz Herrera. Barcelona, Océano, 2000.

Garcia Alonso, J.L.: «Si los dioses hacen algo vergonzoso, no son dioses», Intertextualidad 59-76.

GonZÁlez Merino, J.I.: «Penteo el efebo», Actas del X Congreso I, 453-458.

LÓPEZ GALOCHA, M.D.: «Medea de Eurípides: la cólera justa», Actas del X Congreso I, 469-474.

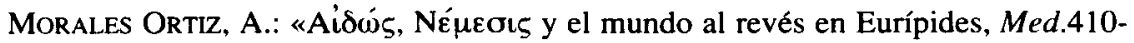
445», Emerita 68, 2000, 291-306.

MuÑoz llamosas, V.: «La muerte de Polixena: una transgresión de aidús», Actas del $X$ Congreso I, 565-571.

ROMERo MARISCAL, L.: «Aproximación al lenguaje político de la Alcestis de Eurípides», Actas del X Congreso 1, 603-609.

WHITE, H.: «Notes on the text of Euripides», Myrtia 15, 2000, 51-68.

\section{Ezechiel}

XANTHAKIS-KaRAmanOS, G.: «The fusion of literary genres and the influence of fifthcentury drama in the Exagoge of Ezekiel», Actas del X Congreso 1, 673-680.

\section{Galenus}

VOlPe CACCIATORE, P.: «El régimen según Galeno», Dieta mediteránea 91-101. 


\section{Gorgias}

Seonne Pardo, A.M.: «La filosofía como retórica. Actualidad de Gorgias», Retórica, política e ideología 185-195.

\section{Gregorius Nazianzenus}

Gómez Villegas, N.: Gregorio de Nazianzo en Constantinopla. Ortodoxia, heterodoxia y régimen teodosiano en una capital cristiana. Madrid, Consejo Superior de Investigaciones Científicas, 2000.

\section{Hanno}

Mederos Martín, A.; Escribano CoBo, G.: «El periplo norteafricano de Hannón y la rivalidad gaditano-cartaginesa de los siglo IV-III a.C.», Gerión 18, 2000, 77-107.

\section{Hecataeus}

Merino MARTínez, J.I.: «La racionalización del mito en Acusilao, Hecateo y Helánico»; Actas del X Congreso I, 527-532.

\section{Heliodorus}

JiMéNEZ LóPEZ, M.D.: «El viaje novelesco de Teágenes y Cariclea», Feliz quien como Ulises 183-214.

\section{Hellanicus}

MERINo MARTínEZ, J.I.: «La racionalización del mito en Acusilao, Hecateo y Helánico»; Actas del X Congreso I, 527-532.

\section{Heraclitus}

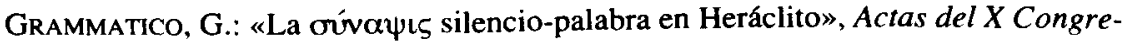
so $I, 459-467$. 
Grammatico, G.: «Tacto, gusto y olfato en los fragmentos de Heráclito», 'Erıeíkela 212-220.

PAPADIS, D.: «Die Ontologie als Grundaspekt der Philosophie von Heraklit», SPHV $4,2000,73-81$.

\section{Herennius Philo Byblius}

CORS I MEYA, J.: «Traces of the Ancient Origin of some Mythic Components in Philo of Byblos' Phoenician History", AuOr 17/18, 1999/2000, 341-348.

\section{Hermogenes rhetor}

Ruiz YamuZA, E.: «Más sobre los Progymnasmata atribuidos a Hermógenes», Habis $31,2000,293-309$.

\section{Herodotus}

AdIEGo, I.X.: «Kandaules Myrsilos», AuOr 17/18, 1999/2000, 453-454.

LOPEZ FéreZ, J.A.: «El léxico de la educación en Heródoto y Tucídides», Actas del $X$ Congreso I, 203-210.

SCHLOGL, A.: Heródoto. Traducción de J.A. López. Madrid, Aldebarán, 2000.

STRIANO, A.: «Heródoto. La curiosidad científica», Feliz quien como Ulises 39-54.

\section{Hesiodus}

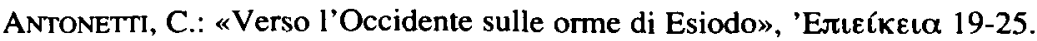

\section{Hippocrates et Corpus Hippocraticum}

CAPRIGLIONE, J.C.: «La diaita secondo Galeno», CFCG 10, 2000, 155-172.

García GuAL, C.: «Dieta hipocrática y prescripciones alimenticias de los pitagóricos», Dieta mediteránea 43-67.

IRMER, D.: «Los estudios hipocráticos en el Thesaurus de Hamburgo: el Thesaurus Linguae Graecae Hamburgensis», Tempus 25, 2000, 5-28.

Rodríguez Alfageme, I.: «Patología de la voz en el Corpus Hippocraticum», CFCG $10,2000,121-154$. 


\section{Hipponax}

WHITE, H.: «Two epigrams on Hipponax», Myrtia 15, 2000, 259-263.

\section{Homerus}

CONTI JiMÉNEZ, L.: «Perturbaciones mentales en los poemas homéricos y en las tragedias de Sófocles y Eurípides», Myrtia 15, 2000, 35-50.

Díaz LAVADO, J.M.: «Textos escolares griegos: una introducción al estudio de Homero en las escuelas del Egipto grecorromano", $A E F$ 23, 2000, 77-88.

FuCHS, E.: «Kämpferisches Fehlverhalten und soziale Kontrolle in der llias», SPhV $4,2000,13-40$.

Gallé Cejudo, R.J.: «La exégesis homérica en la paráfrasis filostratea del escudo de Aquiles (Philostr.Iun.Im. 10.4-20 - Hom.Il. 18.478-608», Actas del X Congreso $I, 409-414$.

GaRCía López, J.; MoRales OTAL, C.: «Los amores del héroe homérico», 'Ẽtıíkela 121-138.

Homero: La Ilíada. Traducción de L. Segalá y Estelella. Madrid, ENE-Nuevas Estructuras, 2000.

HoMERo: La Odisea. Traducción de L. Segalá y Estelella. Madrid, ENE-Nuevas Estructuras, 2000.

HOMERo: La lliada. Barcelona, Océano, 2000.

HOMERo: Odisea. Barcelona, Editorial Sol 90, 2000.

HoMEro: La llíada. Traducción de J. Leyva Fernández. Madrid, Libro Hobby Club, 2000.

HOMERO: La Ilíada. Adaptación de R. Conde Obregón. Madrid, Rialp, 2000.

HOMERO: Homeroren Odisearen bertsioa. Traducción al euskera de J. Kruz Igerabide. San Sabastián, Erein, 2000.

Martínez Benavides, M.J.: «La semántica de los Epimerismos de Homero», Actas del Congreso Internacional de Semántica II, 1131-1138.

Megino Rodríguez, C.: «Consideraciones sobre vóos en la llíada», Actas del X Congreso I, 211-218.

Mestre RoCA, F.: «¿Por qué miente Homero? (Una visión histórica de los poemas homéricos en época imperial», Actas del X Congreso I, 532-540.

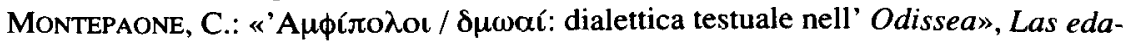
des de la dependencia 29-40.

PÉreZ LOPEZ, M.: «Od.6.-273-315 y A.R.3.771-801: un ejemplo de intertextualidad», Actas del X Congreso I, 581-588.

UREÑA BRACERO, J.: «Etopeya y caracterización en escolios y comentarios homéricos», AEF 23, 2000, 453-469. 
VEGA VeGa, M.M.: «Casandra y su vocabulario mágico en Homero y Esquilo», Actas del X Congreso I, 657-663.

\section{Hymni Homerici}

Himnos homéricos. Batracomiomaquia. Edición de M.A. García Velázquez. Madrid, Akal, 2000.

Torres Guerra, J.B.: «Focalización (puntos de vista) en el Himno a Dioniso (H.Hom.VII)», Actas del X Congreso I, 651-656.

\section{Iamblichus}

SMITH, A.: «Iamblichus, the first philosopher of religion?», Habis 31, 2000, 345-353.

\section{Incerti auctoris Lesbii fragmenta}

RODRIGUEZ SOMOLINOS, H.: «Sobre los Incertum utrius auctoris fragmenta lesbios», Actas del X Congreso I, 595-601.

\section{Iosephus}

BEGG, C.T.: «The retellings of the story of Judges 19 by Pseudo-Philo and Josephus: a comparison", $E B$ 58, 2000, 33-49.

Simoes Rodrigues, N.: «O Judeu e a Egiípcia: o retrato de Cleópatra em Flávio Josefo", Polis 11, 1999, 217-259.

\section{Iuba}

García García, A.M.: «Un autor casi desconocido de la literatura griega: Juba II, rey de Mauritania», Actas del X Congreso I, 415-423.

\section{Libanius}

MuÑIz Grualvo, E.: «El ideal imperial en la obra de Libanio», Habis 31, 2000, 355 363. 


\section{Longus}

Longo: Dafnis y Cloe. Traducción de J. Valera. Madrid, Koty, 2000.

Longo: Dafnis y Cloe. Traducción de J. Valera. Benalmádena, Caligrama, 2000.

\section{Lucianus}

AguirRe CASTRO, M.: «Verdad o mentira: lo mitológico y lo fantástico en Luciano», CFCG 10, 2000, 219-228.

BARRIGON, C.: «Luciano y la creencia en los oráculos», Creencias y supersticiones 23-42.

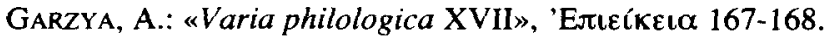

Hoz Montoya, J. DE LA: «Ś́strato, un evérgeta beocio», Habis 31, 2000, 311-325. Jufresa, M.; Mestre, F.; GóMEz, P.: «Belleza y elocuencia, o la rendición por los sentidos (Lucianus, Scyth.11)», Emerita 68, 2000, 269-278.

Lizcano Rejano, S.M.: «El Tóxaris de Luciano de Samósata: un paradigma de la amistad entre griegos y bárbaros», CFCG 10, 2000, 229-252.

\section{Lycophro}

Clúa SerenA, J.A.: «Lycophronea», Actas del X Congreso 1, 357-362.

\section{Lyrica iambica adespota}

TORNÉ TEIXIDO, R.: «El fragmento Adesp.Iamb.2 W² (22 D., 20A B.) (= Cic.Ad Att.VI 3,1)», Actas del X Congreso I, 647-650.

\section{Lysias}

LISIAS:Discursos. Vol.III: Discursos XXVI-XXXV. Fragmentos. Texto revisado y traducido por J.M. Floristán Imízcoz. Madrid, Consejo Superior de Investigaciones Científicas, 2000.

\section{Marcus Aurelius Antoninus}

DAURELlA, F.: Marco Aurelio. Vida y pensamientos. Barcelona, Viena, 2000. 


\section{Menippus}

ReliHAN, J.C.: Menipo en la antigüedad y en el Renacimiento», Los cínicos 346382 .

\section{Musaeus}

VillarRubia, A.: «Notas sobre el poema Hero y Leandro de Museo», Habis 31, $2000,365-401$.

\section{Nicander Colophonius}

MARTINEZ, S.: «Los Cynegetica fragmentarios y el fracaso del cazador», Myrtia 15 , $2000,177-186$.

\section{Nonnus}

SÁnChez ARTILes, M.: «Nonno, Dionisíacas XXIV, 309-320: la semántica del vocabulario de "tejer" y el himno griego antiguo», Actas del Congreso Internacional de Semántica II, 1191-1204.

\section{Oppianus Anazarbensis}

Silva SánChez, T.: «Notas de métrica y crítica textual a los Halieutica de Opiano de Anazarbo», Actas del X Congreso 1, 622-629.

\section{Orphica}

BeRnABÉ, A.: «Tradiciones órficas en Diodoro», 'E $\pi \iota \varepsilon i ́ k \varepsilon \iota \alpha$ 37-53.

Pórtulas, J.: «Orfeo en Bizancio», 'E $\tau \iota \varepsilon i ́ \kappa \varepsilon \iota \alpha ~ 399-405$.

\section{Pausanias}

Pausanias: Descripción de Grecia. Ática y Élide (Libros I, V y VI). Introducción, traducción y notas de C. Azcona García. Madrid, Alianza, 2000. 


\section{Philo Iudaeus}

BEGG, C.T.: «The retellings of the story of Judges 19 by Pseudo-Philo and Josephus: a comparison», $E B$ 58, 2000, 33-49.

\section{Philostratus Iunior}

GALlÉ CEJUDO, R.J.: «La exégesis homérica en la paráfrasis filostratea del escudo de Aquiles (Philostr.Iun.Im. 10.4-20 - Hom.Il. 18.478-608», Actas del X Congreso I, 409-414.

\section{Pindarus}

GaRCía RAMÓN, J.L.: «Fraseología heredada e innovación en lengua de la lírica co-

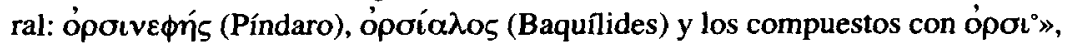

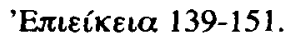

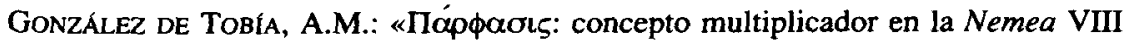

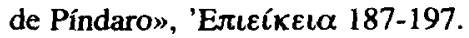

Martinez Manzano, M.T.: «Un nuevo manuscrito de Píndaro: Salmanticensis 769», Emerita 68, 2000, 87-102.

Martínez MarzoA, F.: «Píndato y el libro X de La República de Platón», La razón del mito 200-208.

Martínez Nieto, R.B.: «Valores divinos y humanos en el mundo poético de Píndaro", Actas del X Congreso I, 505-511.

\section{Plato}

AREnas Dolz, F.: «Ver sin ser visto, como Giges: a vueltas con República II 359b.6360d.7», Actas del X Congreso 1, 323-328.

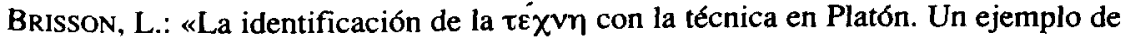

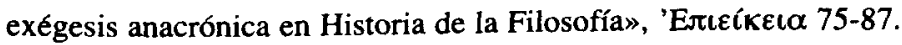

CASADESús Bordoy, F.: «Nueva interpretación del Crátilo platónico a partir de las aportaciones del papiro de Derveni», Emerita 68, 2000, 53-71.

Díaz de Cerio Díez, M.; Serrano Cantarín, R.: «Sobre algunos aspectos de la descripción del universo interior de Sócrates", Actas del X Congreso 1, 377-383.

Diaz de Cerio Diez, M.; Serrano Cantarín, R.: «Los Excerpta del Protágoras de Platón contenidos en el ms. Escorialensis X. I. 13 (Esc)», Habis 31, 2000, 8998. 
Fernández García, A.J.: «La teoría musical de Platón en el tratado De Musica de Ps. Plutarcon, Actas del X Congreso I, 391-399.

Giménez Pérez, F.: Physis, logos y polis. La filosofía política de Platón y Aristóteles. Madrid, F. Giménez-Pérez - Sociedad de Estudios de Filosofía Materialista, 2000.

González Rolán, T.; Saquero Suárez-Somonte, P.: «El axíoco pseudo-platónico traducido e imitado en la Castilla de mediados del s. XV. Edición de la versión romance de Pedro Díaz de Toledo y de su modelo latino», CFCL 19, 2000, 157-197.

LÓPEZ AGUAYo, F.: «La Atlántida vista por un geólogo: una aproximación al mito de Platón», Cal.Ren.1, 2000, 189-208.

Martínez MarzoA, F.: «Píndaro y el libro X de La República de Platón», La razón del mito 200-208.

Platón: Gorgias. Edición crítica, traducción, introducción y notas de R. Serrano Cantarín y M. Díaz de Cerio Díez. Madrid, Consejo Superior de Investigaciones Científicas, 2000.

Platón: Diálogos. Madrid, Libsa, 2000.

Platón: Menón o sobre la virtud. Edición preparada por J. Echegoyen Olleta y M. García-Baró. Traducción de M. García-Baró. Madrid, Mare Nostrum Comunicación, 2000.

Platón: La República. Madrid, M.E. Editores, 2000.

Platón: La Républica. Diálogos. Madrid, Edimat, 2000.

Platón: Sokratesen defentsa. Traducción al euskera de J. Peña. San Sebastián, Jakinkizunak, 2000.

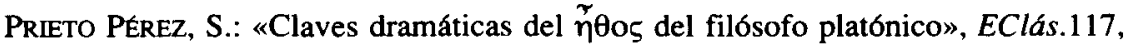
$2000,7-34$.

RosetTI, L.: «L'ideologia filosofica: il caso di Platone», Retórica, política e ideología $169-184$.

SÁNCHEZ DE LA TORRE, Á.: “CCómo contempla la ley a la sociedad, según Platón?», CFCG 10, 2000, 105-120.

\section{Plutarchus}

CABallero, R.: «Notas críticas y exegéticas del De exilio de Plutarco», CFCG 10, 2000, 189-218.

Fernández García, A.J.: «La teoría musical de Platón en el tratado De Musica de Ps. Plutarco», Actas del X Congreso I, 391-399.

Garcia Gual, C.: «El Plutarco de Fray Antonio de Guevara», La herencia greco-latina 65-74.

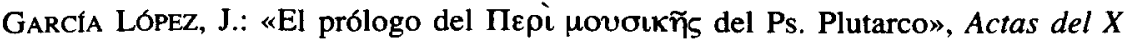
Congreso I, 425-430. 
Morales Ortiz, A.: Plutarco en España. Traducciones de Moralia en el siglo XVI. Murcia, Universidad, 2000.

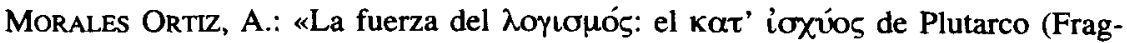
mento 121 Sandbach)", Actas del X Congreso I, 556-564.

PÉrez JiMÉNeZ, A.: «Del Coriolano de Plutarco al Coriolano de Shakespeare: perfiles de un retrato literario», El retrato literario 323-331.

PòRTULAS, J.: «Soló i Epiménides a Atenes», La razón del mito 91-102.

RuIZ LOPEZ, D.: «El verbo $\chi \rho \eta \mu \alpha \tau i \zeta \omega$ y las mujeres licias», Actas del X Congreso I, 263-268.

\section{Polybius}

Pelegrín Campo, J.: «Mercenarios, rebeldes y degradación humana en el relato polibiano de la Guerra Líbica», Polis 11, 1999, 161-195.

\section{Porphyrius Tyrius}

ZAMORA SALAMANCA, M.H.: «Creencias religiosas y pensamiento religioso en el $D e$ philosophia ex oraculis haurienda de Porfirion, Creencias y supersticiones 277-285.

\section{Proclus}

Rodríguez Moreno, I.: «Démones y demónides en Proclo: una cuestión de sexo», Actas del X Congreso I, 588-594.

\section{Procopius}

Procopio de CESAREA: Historia de las guerras. Libros I-II: Guerra Persa. Introducción, traducción y notas de F.A. Garcia Romero. Madrid, Gredos, 2000.

PROCOPIO DE CESAREA: Historia de las guerras. Libros III-IV. Introducción, traducción y notas de J.A. Flores Rubio. Madrid, Gredos, 2000.

PRocopio de Cesarea: Historia secreta. Introducción, traducción y notas de J. Signes Codoñer. Madrid, Gredos, 2000.

\section{Protagoras}

Bayona AzNar, B.: «El covencionalismo político de Protágoras», Polis 11, 1999, 53-83. 
PERPILLOU, J.-L.: «Le genre grammatical: pour Protagoras», Philokypros 251-258. Solana Dueso, J.: El camino del ágora. Filosofía política de Protágoras de Abdera. Zaragoza, Universidad, 2000.

\section{Pythagoras et Pythagorici}

García Gual, C.: «Dieta hipocrática y prescripciones alimenticias de los pitagóricos», Dieta mediteránea 43-67.

\section{Sappho}

SAFo: Obra completa. El Cabanyal, L'Oronella Servicis Editorials Valencians, 2000.

\section{Sextus Empiricus}

Ramos JuRAdo, E.A.: «Sexto Empírico y los alegoristas», Habis 31, 2000, 267-292.

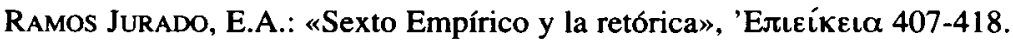

\section{Simonides}

Durán LÓPEZ, M.Á.: «Simónides y la crítica del lenguaje», Actas del X Congreso I, 185-192.

\section{Sophocles}

CONTI, L. JIMÉNEZ: «Perturbaciones mentales en los poemas homéricos y en las tragedias de S6focles y Eurípides», Myrtia 15, 2000, 35-50.

CREspo AlCALÁ, P.: «La caracterización de Antígona a la luz del v. 88 de la tragedia homónima de Sófocles», Actas del X Congreso 1, 371-376.

Fernández VALlejo, A.M.: «Matar después de morir en Sófocles», Actas del X Congreso I, 401-407.

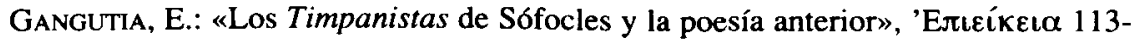
119.

GIL, L.: «De las varias lecturas del Edipo Rey», CFCG 10, 2000, 71-90.

PICKLESIMER, M.L.: «Ismene, una figura incomprendida», FI 11, 2000, 215-225.

SÓFOCles: Edipo Rey. Edipo en Colono. Madrid, M.E. Editores, 2000. 


\section{Sosicrates uel Sostratus poeta}

MARTINEZ, S.: «Los Cynegetica fragmentarios y el fracaso del cazador», Myrtia 15, $2000,177-186$.

\section{Strabo}

Fernández Palacio, F.: «Estrabón e Iberia. A propósito de un libro reciente», Gerión $18,2000,551-570$.

\section{Thales Milesius}

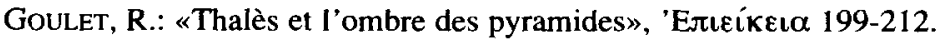

UÑa JuÁREZ, A.: Así nació la filosofía. Sobre el texto de Aristóteles (Metafísica 1,3) en torno a Tales de Mileto. Madrid, A. Uña Juárez, 2000.

\section{Themistius}

Temistio: Discursos políticos. Introducción, traducción y notas de J. Ritoré Ponce. Madrid, Gredos, 2000.

\section{Theocritus}

Calderón, Dorda, E.: «El léxico musical en Teócrito», Habis 31, 2000, 99-112.

Molinos TejadA, M.T.: «Observaciones sobre la lengua de los Idilios XVI y XVII de Teócrito", Actas del X Congreso I, 219-225.

Montes CalA, J.G.: «Adonis y los semidioses: Theoc.15.136-142», Myrtia 15, 2000, 161-176.

\section{Theodoretus Cyrensis}

HILL, R.C.: «Theodoret's commentary on Paul», EB 58, 2000, 79-99.

\section{Theophrastus}

MANZANERo CANo, F.: «Baccare frontem cingite. Eco de una práctica mágica en Virgilio, Buc.VII 27-28», CFCL 19, 2000, 53-57. 


\section{Thucydides}

Classen, C.J.: «Le virtù nell Storie di Tucidide», Actas del X Congreso I, 351-355. LÓPEZ FÉrEZ, J.A.: «El léxico de la educación en Heródoto y Tucídides», Actas del $X$ Congreso I, 203-210.

\section{Xenopho}

Vegas Sansalvador, A.: «La Anábasis de Jenofonte: el deseo del mar», Feliz quien como Ulises 81-101.

\section{Historia de la literatura}

Alvar EzQuerRa, J.: «Fuentes literarias sobre Tartessos», en Aranegui Gascó, C. (ed.): Argantonio, rey de Tartessos. Catálogo de la exposición. Sevilla, Ministerio de Educación y Cultura, 2000, pp. 37-67.

ÁlVAREZ GARCIA, A.: «Soportes de escritura y epístolas en la novela griega y latina», AM 23, 2000. 151-169.

Amado Rodriguez, M.T.: «Los cómicos y el nuevo ditirambo (Ar.Av.1373-1409)», Actas del X Congreso I, 315-322.

Boned Colera, P.: «Sobre un género literario menor: las paremias»; Actas del X Congreso I, 335-341.

BRIOSO SÁNCHEZ, M.: «¿Originalidad y literatura de consumo en la novela griega antigua?: Caritón y Jenofonte de Éfeso (I)», Habis 31, 2000, 177-217.

Brioso SÁNCHEZ, M.: «El debate sobre los dos amores en la literatura imperial»,

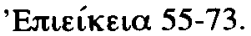

Brioso SÁNCHEZ, M.: «El amor, de la comedia nueva a la novela», Consideraciones en torno al amor 145-225.

Brioso SÁNCHEZ, M.: «Aspectos de intertextualidad genérica en la novela griega antigua», Intertextualidad 121-141.

CABAllero LÓPEZ, J.A.: «Retórica y demagogia: el mito como instrumento de persuasión», Retórica, política e ideología 49-60.

CASCAJERO, J.: «Grupos de edad y relaciones de dependencia en la oralidad antigua. La vejez en los restos orales», Las edades de la dependencia 1-28.

Castillo Bejarano, M.: «EL símil de las grullas en la épica clásica», $C F C L 18$, $2000,137-162$.

CORTÉs GABAUdÁN, F.: «La retórica en la asamblea ateniense», Retórica, política e ideología 61-74.

CRESPO, E.: «La lengua y la escritura en las utopías de la literatura griega antigua», 'Елıєі́кعıа 89-94. 
D'IPPOLITO, G.: «Il concetto di intertestualità nel pensiero degli antichi», Intertextualidad 13-32.

Dízz Platas, F.: «Naturaleza y femineidad. Los epítetos de las ninfas en la épica griega arcaica», $C F C G 10,2000,19-29$.

Dobias-Lalou, C.: «La communication inter-dialectale et son traitement chez les historiens du Ve. et du IVe. siècle», Philokypros 115-128.

Egoscozábal, C.: «Epítetos épicos compuestos más imitados por los líricos arcaicos», Faventia 22/2, 2000, 13-24.

EscoBAR, Á.: «Hacia una definición lingüística del tópico literario», Myrtia 15, 2000, 123-160.

FERNÁNDEZ CONTRERAS, M.A.: «El insomnio como motivo literario en la poesía griega y latina», Habis 31, 2000, 9-35.

FERRATE, J. (ED.): Líricos griegos arcaicos. Barcelona, El Acantilado, 2000.

GALÁN VIOQUe, G.: «Antes la idea que la expresión. Testimonios griegos de una máxima latina», Exemplaria 4, 2000, 261-266.

GARCÍA LÓPEZ, J.: «La música en el desarrollo del género teatral griego: la tragedia», en Historia y humanismo. Homenaje al Prof. P. Rojas Ferrer. Murcia, Universidad, 2000.

Garzya, A.: «El vino en la literatura médica de la Antigüedad tardía y bizantina», CFCG $10,2000,173-188$.

GÓmez ESPELosín, F.J.: El descubrimiento del mundo. Geografía y viajeros en la antigua Grecia. Madrid, Akal, 2000.

IGLESIAS ZOIDO, J.C.: «Oratoria, retórica y escritura en Grecia», $C F C G$ 10, 2000, 39 70.

LÓPEZ EIRE, A.: Esencia y objeto de la retórica. Salamanca, Universidad, 2000.

LOPEZ EIRE, A.; SANTIAGo GUERvós, J. DE:Retórica y comunicación política. Madrid, Cátedra, 2000.

LOPEZ EIRE, A.: «Retórica y política», Retórica, política e ideología 99-140.

LÓPEZ FéreZ, J.A.: «El léxico de la educación en Heródoto y Tucídides», Actas del $X$ Congreso I, 203-210.

LOS DADOS DE EROS. Antología de poesía erótica griega. Edición bilingüe. Introducción, traducción y notas de A. Luque. Madrid, Hiperión, 2000.

Martín Velasco, M.J.: «El ejemplo en los discursos judiciales», Actas del X Congreso I, 491-496.

MARTINEZ, S.: «El poeta i les aus», AF-SGL 21, 1998/99, 107-122.

MARTINEZ HeRnÁNDEZ, M.: «Los géneros eróticos de la literatura griega», Actas del $X$ Congreso $1,497-504$.

Melero, A.; MARTf́, P.: «Representaciones del Más Allá en la comedia ática antigua", Actas del X Congreso I, 513-526.

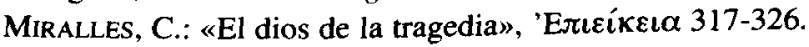

MrtuAns, E.: «Comèdia i espai públic», AF-SGL 21, 1998/99, 123-130. 
MONTAÑEs GÓMEZ, R.: «El vi i l'embriaguesa a la comèdia: consideracions, judicis i imatges», $S P h V 4,2000,41-56$.

MONTAÑÉs GómEZ, R.: «Las mujeres y la mujer en los títulos y fragmentos de la comedia griega", Actas del $X$ Congreso I, 550-556.

ORADORES MENORES. DISCURSOS Y FRAGMENTOS. Introducción, traducción y notas de J.M. García Ruiz. Madrid, Gredos, 2000.

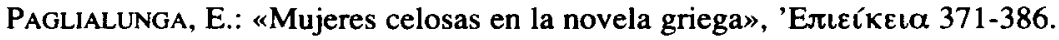

Perea Yébenes, S.: Mitos griegos e historiografía antigua. Sevilla, Padilla, 2000.

Pordomingo, F.: «Poesía popular y poesía literaria griegas: relaciones intertextuales», Intertextualidad 77-104.

Portulas, J.: «Poetas míticos de Grecia», Actas del X Congreso I, 289-312.

QuiJaDA, M.: «El festival de Dioniso: un marco propicio para la intertextualidad», Intertextualidad 41-57.

RAMírEZ DE VERGER, A.: «Una juntura literaria de la puella pudica en Ovidio, Amores 2.4.11», Exemplaria 4, 2000, 249-256.

Rocco,C.: Tragedia e ilustración. El pensamiento político ateniense y los dilemas de la modernidad. Traducción de C. Gardini. Barcelona, Andrés Bello, 2000.

RODRíGUEZ ADRADOS, F.: «Teoría y puesta en escena del teatro clásico», Actas del X Congreso 1, 89-93.

Ruiz SolA, A.: «El trasfondo mítico de la naturaleza en la tragedia griega», Actas del $X$ Congreso I, 611-616.

SANCHís LLOPIS, J.L.: «Circe y Calipso en la comedia griega», Actas del X Congreso I, 616-622.

SANCHO, A.: «La retórica en la literatura amorosa griega», Consideraciones en torno al amor 70-101.

SERGHIDOU, A.: «Relations de dépendance et servitude dans la tragédie grecque», Las edades de la dependencia 101-112.

Souto Delibes, F.: «La crítica de los poetas trágicos en la comedia griega antigua», EClás.118, 2000, 11-26.

VílChEZ, M.: «Individuo, sociedad y tragedia», Actas del X Congreso I, 109-111.

VILlarrubia, A.: «El amor en la poesía lírica de la época arcaica», Consideraciones en torno al amor 11-68.

VINAGRE, M.Á.: «La tragedia griega del siglo IV a.C.: nuevas perspectivas», Actas del X Congreso I, 665-671.

\section{Lingǘstica. Métrica}

AdIEGO, I.X.: «Kandaules Myrsilos», AuOr 17/18, 1999/2000, 453-454.

BERENGUER SÁNCHEZ, J.A.: «Algunas precisiones sobre la etimología del pronombre interrogativo-indefinido griego y latino», Actas del X Congreso I, 169-175. 
BONED COlera, P.: «El sufijo - $\omega \mu \alpha$ en la terminología médica», Actas del Congreso Internacional de Semántica II, 1053-1058.

BROCK, S.P.: «El griego y el siríaco en la antigua Siria tardía», Cultura escrita y poder 235-251.

BUENO, M.: «Los antropónimos en - ás como rasgo de diferenciación dialectal dentro del jónico ático", Actas del X Congreso I, 177-184.

CASADESÚS BORDOY, F.: «Algunas consideraciones sobre la formación del vocabulario filosófico", Actas del Congreso Internacional de Semántica II, 1059-1070.

CASADESÚs BordoY, F.: «Nueva interpretación del Crátilo platónico a partir de las aportaciones del papiro de Derveni», Emerita 68, 2000, 53-71.

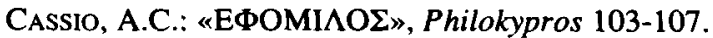

DETTORI, E.: «BPYXA^EIO $\Sigma$ in un' iscrizione tessala», Myrtia 15, 2000, 27-34.

Díez PLATAS, F.: «Los epítetos del amor y el deseo en la épica griega arcaica», Actas del $X$ Congreso I, 385-390.

Dobias-Lalou, C.: «La communication inter-dialectale et son traitement chez les historiens du Ve. et du IVe. siècle», Philokypros 115-128.

DOMfNGUEZ MONEDERo, A.J.: «Más allá de Heracles: de la Iberia real a la recreación de la Iberia griega», Los griegos en España 39-51.

Duhoux, Y.: «Particules à emploi métrique selon Denys le Thrace», Emerita 68, $2000,31-46$.

DURÁN, M.Á.: «Las partículas griegas y las funciones de comunicación», R.S.E.L. 30, 2000, 45-76.

EGETMEYER, M.: «Les syllabogrammes en $y$ - dans le syllabaire chypriote», Philokypros 137-152.

EgoscozÁbal, C.: «Epítetos épicos compuestos más imitados por los líricos arcaicos», Faventia 22/1, 2000, 13-24.

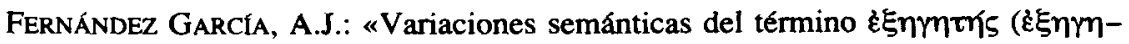

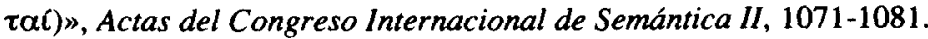

FERNÁNDEZ GARRIDO, R.: «La determinación en griego antiguo: el articulo», Habis $31,2000,465-479$.

FORTES FORTES, J.: «Micénico ku-pa-ro = PYC/CYP y los determinativos $O, K U, P A$ y $Q A \gg$, Faventia 22/2, 2000, 7-12.

GaRcía Novo, E.: «El dístico elegíaco arcaico: nueva definición de su estructura», CFCG 10, 2000, 9-18.

GaRcia RAMÓN, J.L.: «Fraseología heredada e innovación en lengua de la lírica co-

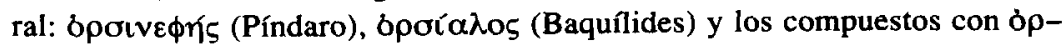

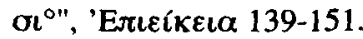

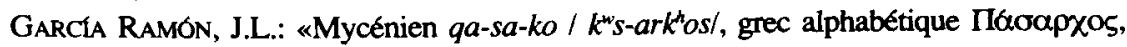
Ktrio $\alpha \rho \chi 0 \zeta$ et le dossier de *ku- dans la langue des tablettes», Philokypros 153-176.

GuZMán Guerra, A.: «Desvíos semánticos en griego clásico», Actas del Congreso Internacional de Semántica II, 1083-1095. 
IRIGOIN, J.: «Problèmes de diphtongues en grec ancien (graphie et accentuation)», Philokypros 183-190.

JIMÉNEZ LÓPEZ, M.D.: «El marco predicativo del verbo $\pi \varepsilon ́ \mu \pi \omega »$, Actas del X Congreso I, 193-201.

LABIANO ILUNDÁIN, J.M.: Estudio de las interjecciones en las comedias de Aristófanes. Amsterdam-Las Palmas, Hakkert, 2000.

LARA NAVA, M.D.: «Estudio semántico de un término médico griego: óváôooıৎ», Actas del Congreso Internacional de Semántica II, 1097-1104.

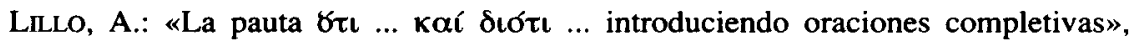

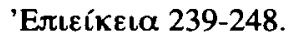

LeUKART, A.: «Le nom d'Aristote», Philokypros 201-208.

LOPEZ EIRE, A.: «Historia del ático a través de sus inscripciones III», Zephyrus 52, 1999, 221-238.

LÓPEZ PEGo, A.: «Evolución del significado de $\theta \varepsilon ́ \lambda \eta \mu \alpha$ voluntad del Antiguo al Nuevo Testamento», EB 58, 2000, 309-346.

MARTÍN MARTín, D.: «Los verbos de "amar" en un léxico bizantino inédito», Actas del Congreso Internacional de Semántica II, 1105-1114.

Martínez Benavides, M.J.: «La semántica de los Epimerismos de Homero», Actas del Congreso Internacional de Semántica II, 1131-1138.

MARTÍNEZ FernánDEZ, Á.: «Estudio sobre el vocabulario económico en el dialecto cretense», Actas del Congreso Internacional de Semántica II, 1139-1150.

MARTINEZ HERNÁNDEZ, M.: «Para una semántica del griego antiguo», Actas del Congreso Internacional de Semántica II, 1115-1130.

MARTINEZ VÁzQUEZ, R.: «La función semántica agente en griego antiguo», Habis 31 , 2000, 481-502.

Megino Rodríguez, C.: «Consideraciones sobre vóos en la lliada», Actas del X Congreso I, 211-218.

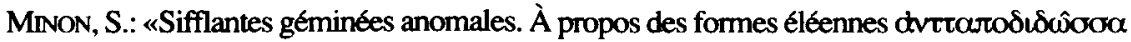

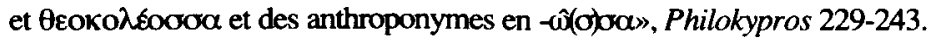

Molinos Tejada, M.T.: «Observaciones sobre la lengua de los Idilios XVI y XVII de Teócrito", Actas del X Congreso I, 219-225.

MontepaOne, C.: «'A $\mu \phi i ́ \tau o \lambda o l ~ / ~ \delta \mu \omega \alpha i ́$ : dialettica testuale nell’ Odissea», Las edades de la dependencia 29-40.

Neumann, G.: «'Pí $\mu \phi \alpha$ und ra-ka-wo-se», Philokypros 245-250.

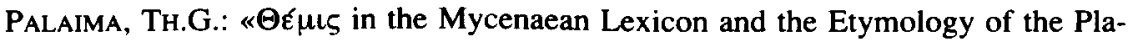
ce-Name *ti-mi-to-a-ko», Faventia 22/1, 2000, 7-19.

PelÁz, J.: «Significado/traducción y definición de las palabras en el Diccionario

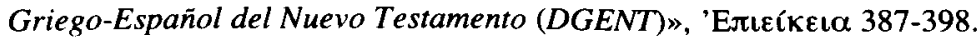

Peláez Del Rosal, J.: «Del lexema al lema. Pasos para la redacción de los lemas del Diccionario Griego-Español del Nuevo Testamento", Actas del Congreso Internacional de Semántica II, 1151-1159. 
Pereiro Pardo, A.: «Estudio léxico de los verbos que expresan el orto de los astros en los Fenómenos de Araton, Actas del X Congreso 1, 227-233.

PÉrez MARTEL, J.M.: "Semántica y hermenéutica en los escolios y glosas de las tragedias de Esquilo», Actas del Congreso Internacional de Semántica II, 1161 1174.

Perpillou, J.-L.: «Le genre grammatical: pour Protagoras», Philokypros 251-258.

POMPEI, A.: «La categoría del participio: formas y función discursiva», Actas del X Congreso 1, 243-251.

Revuelta Puigdollers, A.: «Parallel focus particles, specially in Ancient Greek», Actas del Congreso Internacional de Semántica II, 1175-1190.

Revuelta Puigdollers, A.: «La función compañía en griego antiguo», Actas del X Congreso I, 253-261.

REYNOLDS, J.: «Libyan names», Philokypros 259-262.

RoDrígueZ ADRADOS, F.: «La semántica en el Diccionario Griego-Español», Actas del Congreso Internacional de Semántica I, 99-110.

Rodríguez Adrados, F.: «Topónimos griegos en Iberia y Tartessos», Emerita 68, $2000,1-18$.

Romero MARISCAL, L.: «Aproximación al lenguaje político de la Alcestis de Eurípides», Actas del X Congreso I, 603-609.

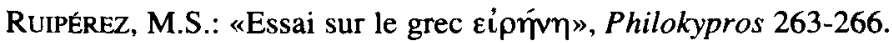

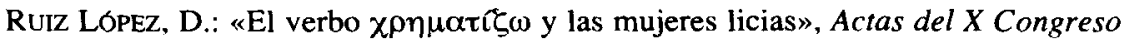
I, 263-268.

SÁNCHEZ ARTILES, M.: «Nonno, Dionisíacas XXIV, 309-320: la semántica del vocabulario de "tejer" y el himno griego antiguo", Actas del Congreso Internacional de Semántica II, 1191-1204.

Santana Henríuez, G.: Semántica y lingüistica. Aplicación del método de la Sprachinhaltsforschung al griego antiguo. Las Palmas, Universidad, 2000.

Santana Henríquez, G.: «Estudio semántico de los compuestos con $\beta a \theta v$ - en griego antiguo I», Actas del Congreso Internacional de Semántica II, 1205-1217.

SERRANO AYBAR, C.: «Algunas consideraciones semánticas sobre el adverbio Érrúş", Actas del Congreso Internacional de Semántica II, 1219-1227.

Solin, H.: «De Bérenike à Veronique», Philokypros 277-284.

SOUTO DeliBes, F.: «El participio regido ¿una isoglosa indoeuropea?», Actas del X Congreso I, 269-275.

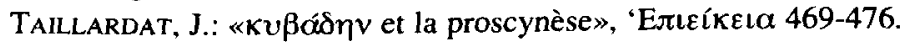

VEGA VEGA, M.M.: «Casandra y su vocabulario mágico en Homero y Esquilo», ACtas del X Congreso 1, 657-663.

VILLA POLO, J. DE LA: «La semántica de la sintaxis en griego antiguo y latín», Actas del Congreso Internacional de Semántica II, 1229-1245.

VILLA POLO, J. DE LA: «La subordinación en griego antiguo: análisis y perspectivas», Actas del X Congreso I, 117-165. 
Zamora Salamanca, M.H.: «El período condicional en el dialecto de Cos», Actas del $X$ Congreso I, 277-283.

\section{Micenología}

FORTES FORTES, J.: «Micénico ku-pa-ro = PYC/CYP y los determinativos $O, K U, P A$ y $Q A »$, Faventia $22 / 2,2000,7-12$.

GaRcia RAMÓN, J.L.: «Mycénien qa-sa-ko / $k^{w} s-a r k^{h} o s /$, grec alphabétique Пóóap-

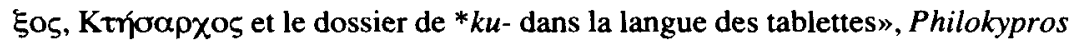
153-176.

Palaima, TH.G.: « $\Theta \varepsilon \in \mu \mathrm{s} \varsigma$ in the Mycenaean Lexicon and the Etymology of the PlaceName *ti-mi-to-a-ko», Faventia 22/1, 2000, 7-19.

\section{Epigrafia. PAPIROLOGIA}

BAKER, P.: «La cause du conflit entre Mélitéa et Narthakion: une note à propos de $I G$ IX 2,89", Philokypros 33-47.

BiLE, M.: «À propos de deux épigrammes funéraires crétoises», Philokypros 49-60.

BRIXHE, C.: «Les ardoises de l'Académie. Histoire exemplaire d'un dossier délicat», Philokypros 61-89.

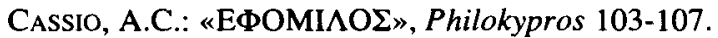

Chamoux, F.: «Sur une épigramme de Tocra», Philokypros 109-114.

DETTORI, E.: «BPYXA\EIO $\Sigma$ in un' iscrizione tessala», Myrtia 15, 2000, 27-34.

DuboIs, L.: «L'une des plus vieilles inscriptions rhodiennes», Philokypros 129-135. Hatzopoulos, B.: «Une famille bien macédonienne», Philokypros 177-182.

Hoz, J. DE: «Epigrafía griega de occidente y escritura greco-ibérica», Los griegos en España 165-175.

KrITZAS, C.B.: «La dédicace argienne attribué à Wriknidas», Philokypros 191-195.

LAZZARINI, M.L.: «Un nome femminile sibarita», Philokypros 197-199.

MARTIN RodRígueZ, D.: «Tarjetas y cartas de invitación en papiros griegos», Actas del $X$ Congreso I, 485-490.

PEREA YÉbenes, S.: «El epitafio de un soldado de Miseno y los stratores (nota para Yann Le Bohec)», Gerión 18, 2000, 593-599.

Thompson, D.J.: «Cultura escrita y poder en el Egipto ptolemaico», Cultura escrita y poder 111-134.

WOOLF, G.: «El poder y la difusión de la escritura en Occidente», Cultura escrita y poder 135-157.

\section{HistoRIA DE LOS TEXTOS}

Durán, M.: «Alguns texts en grec de Bonaventura Serra Ferragut», $A F-S G L$ 21, 1998/99, 83-106. 
González Rolán, T.; Saquero SuÁrez-Somonte, P.: «El Axíoco pseudo-platónico traducido e imitado en la Castilla de mediados del s. XV. Edición de la versión romance de Pedro Díaz de Toledo y de su modelo latino", $C F C L 19,2000,157$ 197.

HernÁndez Mữoz, F.G.: «Notas al Matritensis núm. 4647: Constantino Láscaris y el texto de Demóstenes», CFCG 10, 2000, 253-266.

Martinez Manzano, M.T.: «Un nuevo manuscrito de Píndaro: Salmanticensis 769», Emerita 68, 2000, 87-102.

Pòrtulas, J.: «Orfeo en Bizancio», 'Erıદíkela 399-405.

SPOERRI, W.: «À propos du Diodore d' Henri Estienne (Genève 1559): impressions grecques à Genève au XVIe. siècle», 'Eлıєíkєı $\alpha$ 419-438.

ZAMORA, M.J.: «Evolución gráfica en Constantino Láscaris», CFCG 10, 2000, 267 282.

\section{Historia. Cultura. Sociedad}

Alfaro Giner, C.; TiRado Pascual, M. (EDs.): La mujer en la antigüedad. Actas del Segundo Seminario de Estudios sobre la Mujer. Valencia, Universidad, 2000.

Alonso, J.C.: Arganthonio, rey de Tartessos (670-550 a.C.) Burgos, La Olmeda, 2000.

AlVAR, J.: «Alejandro, explorador y hombre de ciencia», Alejandro Magno 83-98.

BARCELO, P.: «Alejandro Magno: de rey macedónico a monarca universal», Alejandro Magno 45-57.

BlÁzquez, J.M.: Los pueblos de España y el Mediterráneo en la Antigüedad. Estudios de arqueología, historia y arte. Madrid, Cátedra, 2000.

BlázQuEZ, J.M.: «Alejandro Magno, homo religiosus», Alejandro Magno 99-152.

BOARDMAN, J.: Los griegos en ultramar. Comercio y expansión colonial antes de la era clásica. Madrid, Akal, 2000.

Bowman, A.K.; WoOLF, G.: «Cultura escrita y poder en el mundo antiguo», Cultura escrita y poder 11-33.

BROCK, S.P.: «El griego y el siriaco en la antigua Siria tardía», Cultura escrita y poder 235-251.

Caratini, R.: Alejandro Magno. Traducción de M. Armiño. Barcelona, Plaza \& Janés, 2000.

CASCAJERO, J.: «Género, dominación y conflicto: perspectivas y propuestas para la historia antigua», Género, dominación y conflicto 23-47.

CASCAJERO, J.: «Grupos de edad y relaciones de dependencia en la oralidad antigua. La vejez en los restos orales», Las edades de la dependencia 1-28.

CID LóPEZ, R.M.: «Cleopatra: mitos e historia en torno a una reina», Género, dominación y conflicto 119-141. 
Diano, C.: Forma y evento. Principios para una interpretación del mundo griego. Prefacio de R. Bodei. Traducción de C. Rendueles. Madrid, Visor, 2000.

Dickinson, O.: La Edad del Bronce egea. Traducción de P. López Barja de Quiroga. Madrid, Akal, 2000.

DOMínGUEZ MONEDERo, A.J.: «Entre mito e historia: Alejandro y la reina de las Amazonas»; Alejandro Magno 171-198.

Duby, G.; Perrot, M. (dirs.): Historia de las mujeres en Occidente. Tomo I: La Antigüedad. Dirección de P. Schmitt Pantel. Revisión técnica y coordinación del volumen de R. Pastor. Traducción de M.A. Galmarini y C. García Ohlrich. Madrid, Taurus, 2000.

Elvira BARBA, M.Á.: «Observaciones iconográficas sobre el carro funerario de Alejandrom, Alejandro Magno 199-218.

FERNÁNDEZ NIETO, F.J.: «Disciplina y justicia militar en el ejército macedonio en tiempos de Alejandro», Alejandro Magno 59-81.

Gómez EsPelosín, F.J.: El descubrimiento del mundo. Geografía y viajeros en la antigua Grecia. Madrid, Akal, 2000.

GonzÁlez AJA, T.: El deporte a través del arte. Madrid, Comunidad Autónoma, 2001.

Gozalbes Craviolo, E.: Caput Celtiberiae. La tierra de Cuenca en las fuentes clásicas. Cuenca, Diputación, 2000.

IRIGOYEN, R.: Las anécdotas de Grecia. Macedonia de humor. Barcelona, Planeta, 2000.

LEVEQQUE, P.: «Tras Alejandro ... un nuevo oriente. Las mutaciones del fantasmático», Alejandro Magno 219-228.

LOZANO, A.: «Alejandro ante el cínico Diógenes: la confrontación del pensamiento y la acción», Alejandro Magno 153-169.

LozANo, A.: «Alejandro Magno: la apertura de Asia», Feliz quien como Ulises 103-126.

Mirón PÉREz, M.D.: «El gobierno de la casa en Atenas clásica: género y poder en el oikos», Género, dominación y conflicto 103-117.

NAFISSI, M.: «Los syssítia espartanos», Dieta mediteránea 21-42.

PÉREZ JIMÉNEZ, A.: «Introducción. Dieta mediterránea», Dieta mediteránea 1-5.

PÉREZ JiMÉNEZ, F.: «La dieta mediterránea, una herencia cultural saludable», Dieta mediteránea 7-20.

PLÁCIDO SUÁREZ, D.: «Del texto a la historia», Alejandro Magno 33-44.

PLACIDO, SUÁREZ, D.: «La presencia de la mujer griega en la sociedad: democracia y tragedia", Género, dominación y conflicto 49-63.

ROBERTS, J.M.: Historia universal ilustrada. Vol. 1 : Prehistoria y primeras civilizaciones. Asia oriental y Grecia clásica. Barcelona, Plaza \& Janés, 2000.

Rodriguez AdRados, F.: "las imágenes de Alejandro», Alejandro Magno 15-31.

SAlVADOR Ventura, F. (ed.): Hispania meridional durante la Antigüedad. Jaén, Universidad, 2000. 
Thomas, R.: «Cultura escrita y ciudad-estado en la Grecia arcaica y en la Grecia clásica», Cultura escrita y poder 59-85.

Thompson, D.J.: «Cultura escrita y poder en el Egipto ptolemaico», Cultura escrita $y$ poder 111-134.

VANOYeKe, V.: Pericles. Traducción de J.M. Parra Ortiz. Madrid, Aldebarán, 2000.

VANOYeKe, V.: Los Ptolomeos. Últimos faraones de Egipto. Desde Alejandro Magno a Cleopatra. Traducción de J.M. Parra Ortiz. Madrid, Aldebarán, 2000.

WoOLF, G.: «El poder y la difusión de la escritura en Occidente», Cultura escrita y poder 135-157.

ZimmermanN, B.: «Il confronto fra generazioni nell Antichità», Actas del X Congreso I, 681-691.

\section{RELigión. Mitología}

Alvar, J. (DIR.): Diccionario Espasa de Mitologia Universal. Madrid, Espasa, 2000. ARBELOA, V.M.: «Los mitos que me encontré», La razón del mito 24-36.

BuXton, E.: El imaginario griego Los contextos de la mitología. Traducción de C. Palma. Madrid, Cambridge University Press, 2000.

CID, C.; RIU, M.: Historia de las religiones. Barcelona, Optima, 2000.

Delgado Delgado, J.A.: Sacerdocios y sacerdotes de la antigüedad clásica. Madrid, Ediciones del Orto, 2000.

DétIENNE, M.: «Un fundador puñal en mano en la antigua Grecia», en La Fundación de la Ciudad. Mesopotamia, Grecia, Roma. Barcelona, Centre de Cultura Contemporánia de Barcelona - Institut d'Edicions de la Diputación, 2000, pp. 86-93.

DuCH, LL.: «La vigència del mite», La razón del mito 11-23.

ELIADE, M.: Tratado de historia de las religiones: morfología y dialéctica de lo sagrado. Madrid, Cristiandad, 2000.

Filoramo, G.; Marcello, M.; MASSIMO, R.: Historia de las religiones. Traducción de M. Pons. Barcelona, Crítica, 2000.

FloRes ARROYUELO, F.J.: Del toro en la antigüedad: animal de culto, sacrificio, caza y fiesta. Madrid, Biblioteca Nueva, 2000.

Gallardo LOPEZ, M.D.: Mitología clásica resumida. Reed. Madrid, Ediciones Clásicas, 2000.

Garcia TEIJEIRo, M.: «Magia y supersticiones antiguas en el mundo actual»,

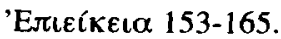

GaRCta VALDÉs, M.: «Religión, superstición y ciencia en la antigüedad griega tardía», Creencias y supersticiones 69-109.

GoMollón, B.: «Ixión y Pirítoo: mortalidad y transgresión en el mito», Actas del X Congreso I, 439-444.

GONZALEZ CORTÉs, M.T.: Eleusis. Los secretos de Occidente. Historia agraria y bélica de la sexualidad. Madrid, Ediciones Clásicas, 2000. 
GONZÁlEZ Delgado, R.: «Eurídice: moritura puella», Actas del X Congreso I, 445-451. GonZÁlez Merino, J.I.: «Penteo el efebo», Actas del X Congreso 1, 453-458.

Goulet-CAZÉ, M.-O.: «La religión y los primeros cínicos», Los cínicos 69-110.

Graves, R.: Dioses y héroes de la antigua Grecia. Traducción de L. Graves. Barcelona, Lumen, 2000.

Grimal, P.: Diccionario de Mitología Griega y Romana. Edición revisada con bibliografía actualizada por el autor. Barcelona, Paidós, 2000.

Guerber, H. A.: Grecia y Roma. Traducción de S. Kwon. Madrid, Edimat, 2000.

HUMBERT, J.: Mitología griega y romana. Barcelona, Gustavo Gili, 2000.

IRIARTE, A.: «Mujer y religión: la Méter en el umbral del III milenio», Género, dominación y conflicto 91-101.

Jonas, H.: La religión gnóstica. El mensaje del Dios Extraño y los comienzos del cristianismo. Prólogo de J. Montserrat Torrens. Traducción de M. Gutiérrez. Madrid, Siruela, 2000.

Jonas, H.: La gnosis y el espíritu de la antigüedad tardía. De la mitología a la filosofía mística. Valencia, Diputación, 2000.

JuARISTI, J.: El bosque imaginario. Genealogías míticas de los pueblos de Europa. Madrid, Taurus, 2000.

LACASA, G.: «La erótica mítica», La razón del mito 215-224.

LEÓN AZCÁRATE, J.L. DE: La muerte y su imaginario en la historia de las religiones. Bilbao, Universidad de Deusto, 2000.

LÓPEZ, H.: «El mito del constitucionalismo», La razón del mito 256-266.

LOPEZ JiMENO, A.: «Maldiciones eróticas y otros encantamientos amorosos. La maldición del amor», Creencias y supersticiones 111-130.

LORA, P. DE: «Ulises y Hércules: dos mitos mediterráneos para la teoría del Derecho contemporánea»; La razón del mito 267-275.

LURI MEDRANO, G.: «El lenguaje del mito», La razón del mito 37-50.

MARCOS CASQUERO, M.A.: Supersticiones, creencias y sortilegios en el mundo antiguo. Cuatro estudios. Prólogo de S. Perea Yébenes. Madrid, Signifer, 2000.

MARCos CAsquero, M.A.: "Creencias y supersticiones relacionadas con el color», Creencias y supersticiones 131-171.

MARCos PÉrez, J.M.: «El adivino bisexual que vaticinó a siete generaciones», Actas del $X$ Congreso $1,475-483$.

Marcos Pérez, J.M.: «La pasión del cisne. El mito de Leda y Zeus en sus fuentes y sus recreaciones», Minerva 14, 2000, 203-231.

MARDONES MARTÍNEZ, J.M.: El retorno del mito. La racionalidad mito-simbólica. Madrid, Síntesis, 2000.

MARTíNEZ, J.: «La música dionisíaca», La razón del mito 209-214.

MARTINEZ NIETO, R.B.: La aurora del prensamiento griego. Las cosmogonías prefilosóficas de Hesíodo, Alcmán, Ferécides, Epiménides, Museo y la Teogonía órfica antigua. Madrid, Trotta, 2000. 
Merino MartíneZ, J.I.: «La racionalización del mito en Acusilao, Hecateo y Helánico»; Actas del X Congreso 1, 527-532.

MeSTRE, F.: «Mite e dona en el mite de Medea», La razón del mito 65-78.

Molina MORENo, F.: «Las sirenas pitagóricas y su trasfondo», Actas del X Congreso I, 541-550.

Molinos TejadA, M.T.: «Superstición, magia y mántica populares en los Bucólicos», Minerva 14, 2000, 49-60.

Muñoz Llamosas, V.: «La muerte de Polixena: una transgresión de aidús», Actas del $X$ Congreso I, 565-571.

Muriel, S.; PlayÀ, R.: «La infância i el mar», La razón del mito 225-240.

Olmos, R.: «Tras los pasos de Heracles: en los umbrales de la historia griega en Occidente», Los griegos en España 27-36.

ORTEGa Villaro, B.: «Epigramas de la Antología Griega relativos a la magia y a la superstición», Creencias y supersticiones 189-200.

Ortiz-OsÉs, A.: «Mitología hispánica. Ángel Álvarez de Miranda», 'Ilu 5, 2000, 119-123.

Perea YéBenes, S.: $\Sigma \phi \rho \alpha \gamma \grave{\varsigma}$ @ $\Theta \varepsilon o \hat{v}$. El sello de Dios. Nueve estudios sobre magia y creencias populares greco-romanas. Madrid, Signifer, 2000.

Perea Yébenes, S.: Mitos griegos e historiografía antigua. Sevilla, Padilla, 2000.

Pérez TRIVIÑo, J.L.: «Razón y mito en la teoría jurídico política», La razón del mito 241-255.

PuIG, J.J.: Así se descubre la mitología Griega y Romana. Barcelona, Cims 97, 2000.

Ressel, M.: «Le metamorfosi del mito di Scilla», Myrtia 15, 2000, 5-26.

SANCHIS LloPIS, J.L.: «Circe y Calipso en la comedia griega», Actas del X Congreso I, 616-622.

Schwab, G.; Dominguez, Á.; Prada, J.M. DE: Dioses y héroes de la Grecia antigua. Traducción de F. Payarols. Barcelona, Juventud, 2000.

SEYFFERT, O.: Diccionario de mitología griega y romana. Traducción de T. Cutanda. Barcelona, Obelisco, 2000.

SMART, N.: Las religiones del mundo. Tradiciones antiguas y transformaciones modernas. Traducción de J. González García. Madrid, Akal, 2000.

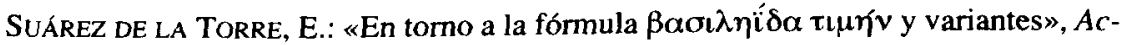
tas del X Congreso I, 631-646.

SuÁREZ DE LA TORRE, E.: «La Sibila de Eritras: análisis de fuentes hasta el siglo II

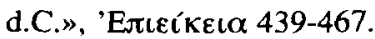

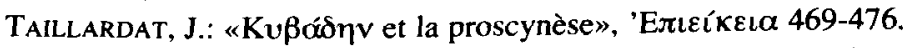

TORIJANO, P.: «El estudio de la magia en la Antigüedad tardía: algunas consideraciones prácticas», Gerión 18, 2000, 535-547.

VALDÉs, M.: «El Teseion, lugar de refugio de esclavos: sus orígenes y función en el ágora vieja de Atenas», Las edades de la dependencia 41-54. 
Vega Vega, M.M.: «Casandra y su vocabulario mágico en Homero y Esquilo», Actas del $X$ Congreso I, 657-663.

VelASCO LÓPEZ, M.H.: «Metamorfosis y videncia en las tradiciones griega e irlandesam, Mienrva 14, 2000, 11-48.

VERNANT, P.: El universo, los dioses, los hombres. El relato de los mitos griegos. Traducción de J. Jorda. Barcelona, Anagrama, 2000.

Vernant, P.: L'univers, els déus, els homes. Traducción de A. Carabén van der Meer. Barcelona, Empúries, 2000.

\section{CRISTIANISMO PRIMITIVO}

ACERBI, S.: El papado en la Antigüedad. Madrid, Ediciones del Orto, 2000.

Alonso, A. (ED.): El mesianismo en el cristianismo antiguo y en el judaísmo. Valladolid, Universidad, 2000.

Cerro Calderón, G. Del: «Condicionamientos de la dieta mediterránea en la moral patrística», Dieta mediteránea 103-124.

Fox, R.L.: «Cultura escrita y poder en el cristianismo», Cultura escrita y poder 199-234.

GOMEZ GALAN, J.: El nacimiento de Jesús de Nazaret: historia y cronología. 3 vols (1 Los orígenes de Jesús: estudio historico, filologico y teológico-exegético del evangelio lucano de la infancia (Lc.1-2); 2 Herodes, los magos y la estrella: crítica histórica y análisis filológico, teológico-exegético y astronómico del evangelio mateano de la infancia (Mt.1-2); 3 La vida oculta de Jesús: nacimiento e infancia de Jesús en el corpus neotestamentario, evangelios apócrifos, fuentes patrísticas, arqueologia e iconografía. Anexos. Compendio final). Madrid, Edisofer, 2000.

ÍñIGUEZ HerRero, J.A.: Arqueología cristiana. Pamplona, Eunsa, 2000.

JoNAs, H.: La religión gnóstica. El mensaje del Dios Extraño y los comienzos del cristianismo. Prólogo de J. Montserrat Torrens. Traducción de M. Gutiérrez. Madrid, Siruela, 2000.

NaDAl Cañellas, J.: Las iglesias apostólicas de Oriente. Historia y características. Madrid, Ciudad Nueva, 2000.

Torres, J.: Los Padres de la lglesia. La sabiduria de sus textos. Madrid, Ediciones Clásicas, 2000.

\section{Filosofía. Ciencia}

BILlERBECK, M.: «El ideal cínico de Epicteto a Juliano», Los cínicos 270-290.

BRUNSCHWIG, J.; LloYd, G.: Diccionario Akal del saber griego. Diccionario crítico. Prefacio de M. Serres; traducción y adaptación de M.P. Boyssou y M.V. García Quintela. Madrid, Akal, 2000. 
CASADESÚs BoRdoY, F.: «Algunas consideraciones sobre la formación del vocabulario filosofico», Actas del Congreso Internacional de Semántica II, 1051070.

GaRCÍA VALDÉs, M.: «Religión, superstición y ciencia en la antigüedad griega tardía", Creencias y supersticiones 69-109.

GiMÉNEZ PÉREZ, F.: Physis, logos y polis. La filosofía política de Platón y Aristóteles. Madrid, F. Giménez-Pérez - Sociedad de Estudios de Filosofía Materialista, 2000.

GodwIN, J.: Armonias del cielo y de la tierra. La dimensión espiritual de la música desde la Antigüedad hasta la vanguardia. Traducción de R. Molina y C. Mora. Barcelona, Paidós, 2000.

GÓMEZ DE LIAÑo, I.: Filósofos griegos, videntes judíos. Madrid, Siruela, 2000.

GoMPERZ, Th.: Pensadores griegos. Una historia de la filosofía de la antigüedad. Vol. 1: De los comienzos a la época de las luces. Vol. II: Sócrates y Plató. Vol. III: Aristóteles y sus sucesores. Dirección de la presente edición de J. Cortés y A. Martínez Riu. Traducción de C.G. Körner et alii. Barcelona, Herder, 2000.

GOULET-CAZE, M.-O.: «La religión y los primeros cínicos», Los cínicos 69-110.

GOULET-CAZE, M.-O.: «Catálogo integral de los filósofos cínicos conocidos», Los cínicos 500-531.

Goulet-Cazé, M.-O.: «¿Quién fue el primer Perto?», Los cínicos 532-534.

GRIFFIN, M.: «El cinismo y los romanos: atracción y repulsión», Los cínicos 251-269.

JoNAS, H.: La religión gnóstica. El mensaje del Dios Extraño y los comienzos del cristianismo. Prólogo de J. Montserrat Torrens. Traducción de M. Gutiérrez. Madrid, Siruela, 2000.

JoNAS, H.: La gnosis y el espíritu de la antigüedad tardía. De la mitología a la filosofía mistica. Valencia, Diputación, 2000.

Lens Tuero, J.; Campos Daroca, J.: Utopias del mundo antiguo. Antología de textos. Madrid, Alianza, 2000.

LONG, A.A.: «Diógenes, Crates y la ética helenística», Los cínicos 45-68.

MIRÓN PÉREZ, M.D.: «Las mujeres, la tierra y los animales: naturaleza femenina y cultura política en Grecia antigua», FI 11, 2000, 151-169.

MOLES, J.L.: «El cosmopolitismo cínico», Los cínicos 142-162».

Martínez, S.: «Anécdotas del elefante filósofo», $F I$ 11, 2000, 137-150.

MARTINEZ NIETO, R.B.: La aurora del prensamiento griego. Las cosmogonías prefilosóficas de Hesiodo, Alcmán, Ferécides, Epiménides, Museo y la Teogonía órfica antigua. Madrid, Trotta, 2000.

MUÑ̃Z JiMÉNEZ, J.M.: «La constante octogonal en el urbanismo de la antigua Grecia (los valore simbólicos de la ciudad ordenada», EClás.117, 2000, 97-113.

PÁNIKer, S.: Filosofía y mística. Una lectura de los griegos. Barcelona, Kairós, 2000. PÉREZ JiMÉnEz, A.: «Peri deípnou. Referencias astrológicas antiguas a la dieta y la gastronomía»; Dieta mediterránea 125-157. 
PIÑERo, A. (ED.): Textos gnósticos. Biblioteca de Nag Hammadi III. Apocalipsis y otros escritos. Madrid, Trotta, 2000.

REALE, G.: La sabiduría antigua. Terapia para los males del hombre de hoy. Traducción de S. Falvino. Barcelona, Herder, 2000.

Rocco,C.: Tragedia e ilustración. El pensamiento político ateniense y los dilemas de la modernidad. Traducción de C. Gardini. Barcelona, Andrés Bello, 2000.

Romm, J.: «Cabezas de perro y nobles salvajes: ¿cinismo antes de los cínicos?», Los cínicos 163-181.

\section{Pervivencia. Humanismo. Historia de la Filología}

Aguinaga Alfonso, M.: «El simbolismo polisémico del Océano a lo largo de las diversas épocas y literaturas», El retrato literario 365-373.

Alvar EzQuerra, A.: "Las universidades y la enseñanza de las lenguas clásicas: perspectiva histórica», Actas del X Congreso 1, 69-73.

ARBELOA, V.M.: «Los mitos que me encontré», La razón del mito 24-36.

ARCAz Pozo, J.L.: «Los mitos clásicos en la poesía española última (1970-1995)», Exemplaria 4, 2000, 33-72.

BarCENILlA, A.: «Filología clásica y Compañía de Jesús. Siglo XVIII», Perficit 24, $2000,3-84$.

BARRIGÓN Fuentes, C.: «La leyenda de Teseo y el laberinto en la obra de Tirso de Molina», La herencia greco-latina 27-44.

BINAGHI, J.: «Mito y ópera», La razón del mito 196-199.

Borrás CASTANYER, L.: «El folle volo de Ulises en la Commedia de Dante», El retrato literario 375-385.

BURKE, P.: El Renacimiento europeo. Barcelona, Crítica, 2000.

CASTRILlo BENITO, N.: «Herencia greco-latina en la lengua y literatura castellanas», La herencia greco-latina 13-18.

ChINCHILLA, P. DE: El libro de la Historia Troyana. Estudio, edición y notas de M.D. Peláez Benítez. Madrid, Universidad Complutense, 2000.

ClAY, D.: «Retratar a Diógenes», Los cínicos 475-499.

CORTÉs Tovar, R.: «Tradición clásica en Epigramas de Ernesto Cardenal», Exemplaria 4, 2000, 211-226.

CRISTÓBAL, V.: «Mitología clásica en la literatura española: consideraciones generales y bibliografía», $C F C L$ 18, 2000, 29-76.

CRISTÓBAL, V.: «La tempestad de Leandro», El retrato literario 419-426.

Cristóbal, V.: «La tradición clásica en la poesía de Luis Barahona de Soton, $C F C L$ $19,2000,199-232$.

DOMINGUEz CAPARRós, J.: «Métrica clásica y verso moderno», El retratro literario 49-69. 
DUCH, LL.: «La vigència del mite», La razón del mito 11-23.

Elvira, M.Á.; SCHRÖder, D.F.: Las criaturas de Prometeo. Esculturas clásicas del Museo Nacional del Prado. Presentación de F. Checa Cremades. Santander, Fundación Marcelino Botín, 2000.

FERnÁndez Valverde, J.: «Tópicos amatorios en El laberinto griego de M. Vázquez Montalbán», Exemplaria 4, 2000, 257-260.

GalÁN Vioque, G.: «Bibliografía para el estudio de la pervivencia literaria de la mitología clásica», Exemplaria 4, 2000, 227-247.

Garcla Gallarfin, C.: «Cultismos léxicos y semánticos en las Medidas del romano (1526) de Diego de Sagredo», Epos 15, 1999, 91-111.

Garcfa Gual, C.: «El Plutarco de Fray Antonio de Guevara», La herencia greco-latina 65-74.

García GuAl, C.: «La cigarra y la hormiga», El retrato literario 499-508.

Garcfa TeIJEIRo, M.: «Magia y supersticiones antiguas en el mundo actual»,

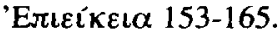

Goethe, J.W.: Ensayos sobre arte y literatura. Edición y prólogo de R.R. de Langbehn. Anejos de Analecta Malacitana 29. Málaga, Universidad, 2000.

González Garrido, G.: El Banquete de Agatona. Comedia en un acto. Madrid, Ediciones Clásicas, 2000.

González Manjarrés, M.A.: Andrés Laguna y el Humanismo médico. Salamanca, Consejería de Educación y Cultura de la Junta de Castilla y León, 2000.

González Manjarrés, M.A.; Conde Parrado, P.: «Dialéctica, retórica y fuentes clásicas en el Coloquio del Porfiado de Pedro Mexía», La herencia greco-latina 75-96.

González Rolán, T.; Saquero Suárez-Somonte, P.: «El axíoco pseudo-platónico traducido e imitado en la Castilla de mediados del s. XV. Edición de la versión romance de Pedro Díaz de Toledo y de su modelo latino», CFCL 19, 2000, 157-197.

HerRero Ingelmo, M.C.: «De los glosarios grecolatinos al castellano medieval: el Alphita", La herencia greco-latina 97-112.

HiNOJO ANDRÉS, G.: «Las universidades y la enseñanza de las lenguas clásicas: perspectica histórica. Las universidades de Hispanoamérica», Actas del X Congreso $1,75-81$.

Hualde Pascual, M.P.: «“... Soñaba con los héroes de la Ilíada”: La obra de Homero en la literatura infantil española de tema clásico (1878-1936)", EClás.118, 2000, 69-92.

Hualde Pascual, M.P.; Hernández Muñoz, F.G.: «La Real Academia Greco-Latina y un discurso griego en defensa de los estudios helénicos», $C F C G 10,2000$, 283-315.

Hualde Pascual, M.P.: «Vidas imaginarias de autores griegos en la literatura moderna: tradición de un microgénero (Schwob, Borges y Tabucchi)», El retrato literario $217-225$. 
KINNEY, D.: «Herederos del perro: la personalidad cínica en la cultura medieval y renacentista», Los cínicos 383-429.

LAGUNA MARISCAL, G.: «El tópico de la tormenta de amor de la poesía grecolatina a la tradición clásica», El retrato literario $435-442$.

LOPEZ, H.: «El mito del constitucionalismo», La razón del mito 256-266.

LÓPEZ EIRE, A.; SANTIAGO GuERvós, J. DE: Retórica y comunicación política. Madrid, Cátedra, 2000.

LÓPEZ FÉREZ, J.A.: «Tradición griega en la literatura castellana (años 1440-1500)»,

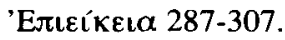

LOPEZ JIMENO, A.: «El mundo sin fronteras de Teo Anguelópulos: odisea cinematográfica a través del mito y la metáfora», EClás.117, 2000, 75-94.

LORA, P. DE: «Ulises y Hércules: dos mitos mediterráneos para la teoría del Derecho contemporánea»; La razón del mito 267-275.

Marcos CASQuero, M.A.: «Supersticiones y creencias en ranas y sapos», La herencia greco-latina 113-146.

Marcos Martinez, A.: El testamento de Aristóteles. Memorias desde el exilio. León, Edilesa, 2000.

Márquez Guerrero, M.Á.: «El susurto de las abejas: Hes.Th.594, Theoc.1.107, Verg.Ecl.1.53-55 y Garcilaso, Églogas 3.79-80», Exemplaria 4, 2000, 283-286.

MartíneZ Garcia, O.: «Algunas apariciones del tema de Teseo en el siglo XX», Exemplaria 4, 2000, 187-210.

Martinez Manzano, T.: «Resonancias clásicas en una novela bizantina: Rodante y Dosicles a la luz de un análisis intertextual», Intertextualidad 143-156.

MAtton, S.: «Cinismo y cristianismo en la Edad Media y en el Renacimiento», Los cínicos 315-345.

Merkel, I.: Ulises y Penélope. Traducción de I. Feuerhake. Barcelona, Folio, 2000.

Montero Cartelle, E.: «La historia de la cultura y su reflejo en la lengua de la medicina», La herencia greco-latina 147-162.

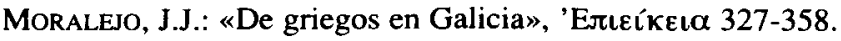

Morales OrTiZ, A.: Plutarco en España. Traducciones de Moralia en el siglo XVI. Murcia, Universidad, 2000.

Morales Peco, M.: «El mito griego como fuente de inspiración de la leyenda de Tristán e Isolda, en unos apuntes inéditos de F. de Saussure: Procris, Hipólito y Enone», Epos 15, 1999, 51-69.

Niehues-PróbSTING, H.: «La recepción moderna del cinismo: Diógenes y la llustración", Los cínicos 430-474.

NiETzSCHE, F.: Escritos sobre retórica. Edición y traducción de L.E. de Santiago Guervós. Madrid, Trotta, 2000.

NIETzSCHE, F.: El nacimiento de la tragedia o Grecia y el pesimismo. Introducción, traducción y notas de Andrés Sánchez Pascual. Madrid, Alianza, 2000. 
OÑATE, T.: El retorno griego de lo divino en la postmodernidad. Una discusión con la hermenéutica nihilista de Gianni Vattimo. Madrid, Aldebarán, 2000.

PEÑa FernándeZ, F.: «Evangelios apócrifos contemporáneos: novelados, revelados y encontrados", 'Jlu 5, 2000, 217-246.

PÉrez Jiménez, A.: «Del Coriolano de Plutarco al Coriolano de Shakespeare: perfiles de un retrato literario», El retrato literario 323-331.

Pérez TRIVIÑo, J.L.: «Razón y mito en la teoría jurídico política», La razón del mito 241-255.

PESET, J.L.: «La renovación del clasicismo en la Ilustración española», Actas del $X$ Congreso I, 83-85.

Petrarca, Bruni, Valla, Pico della Mirandola, Alberti. Manifiestos del humanismo. Selección, traducción, presentación y epílogo de M. Morrás. Barcelona, Península, 2000.

Pomer Monferrer, L.: «Reminiscències explícites de l'Antiguitat greco-llatina al Tirat lo Blanch», SPHV 4, 2000, $117-138$.

Pórtulas, J.: «Orfeo en Bizancio», 'E $\pi \iota \varepsilon i ́ \kappa \varepsilon \iota \alpha$ 399-405.

PRADO, J.M.: «Subversión: elementos clásicos grecolatinos en Reivindicación del Conde Don Julián de Juan Goytisolo», EClás.118, 2000, 51-65.

Prieto ArCiniega, A.: «Cleopatra en la ficción: el cine», Género, dominación y conflicto 143-176.

Relihan, J.C.: Menipo en la antigüedad y en el Renacimiento», Los cínicos 346-382.

RIBEIRO FERREIRA, J. ET ALII: Mitos clássicos na poesia portuguesa contemporânea. Madrid, Edicjones Clásicas, 2000.

RoDRiguez, J.M.: «Pervivencia y transformación del mito clásico durante la Edad Media», La razón del mito 175-187.

RODRÍGUEZ ADRADOS, F.: «Tradición sapiencial antigua y obras árabe-castellanas»,

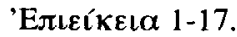

Ruiz SÁnchez, M.: «Temas míticos en dos cuentos de Rubén Darío», Epos 15, 1999, 27-50.

RUIZ SÁNCHEZ, M.: «El motivo de Cupido y la abeja en la poesía neolatina: traducciones y adaptaciones», SPHV 4, 2000, 139-168.

RuIZ SÁNCHEZ, M.: «Los epigramas de Emesto Cardenal: renovación de un género», Exemplaria 4, 2000, 165-186.

Ruiz SolA, A.: «La sentencia y el exemplum en escritos político-morales del siglo XVII español», La herencia greco-latina 191-203.

SALA, T.: «Les encarnacions del mito del Mediterrani en el moviment simbolista», La razón del mito 51-57.

Salmerón CASTRO, A. A.: La herencia de Aristóteles y Kant en la educación moral. Bilbao, Desclée de Brouwer, 2000.

Santana Henríquez, G.: Tradición clásica y literatura española. Las Palmas, Universidad, 2000. 
SCHIPPERS, A.: «The work of Samuel Archivolti (1515-1611) in the Light of the Classical Traditions and Cinquecento Italian literature», Helmantica 51, 2000, 121138.

SCHRADER, L.: «El arte y los dioses antiguos en la obra de Miguel Ángel Asturias. Aporte a la interpretación de Clarivigilia primaveral", AM 23, 2000, 21-56.

SERÉs, G.: «El evemerismo medieval español: de Alfonso el Sabio al Tostado», $L a$ razón del mito 159-174.

SUbIRÁS I PUGIBET, M.. «Mediterrània i Noucentisme», La razón del mito 58-64.

TOMÁS DE AQUINO, SANTO:In decem libros Ethicorum Aristotelis ad Nicomachum expositio. Comentario a la Ética a Nicómaco de Aristóteles. Traducción de A. Mallea. Estudio preliminar y notas de C.A. Lértora Mendoza. Pamplona, EUNSA, 2000.

\section{DiCCIONARIOS. REPERTORIOS. OTROS INSTRUMENTOS}

BRUNSCHWig, J.; LloYd, G.: Diccionario Akal del Saber Griego. Diccionario crítico. Prefacio de M. Serres; traducción y adaptación de M.P. Boyssou y M.V. García Quintela. Madrid, Akal, 2000.

CARRera de LA ReD, A.: «Nota sobre la Filología Clásica en Internet, o el nuevo nacimiento de Minerva», Minerva 14, 2000, 235-238.

DíaZ Tejera, A.: Opera selecta. Sevilla, Universidad, 2000.

DicCionario Griego-español del NUEVO TESTAMENTo. ANÁlisis SEMÁNTICo de loS

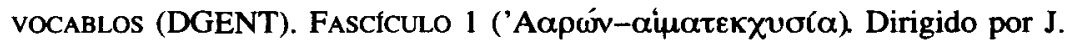
Mateos co la colaboración de J. Peláez y el Grupo de Análisis Semántico de la Universidad de Córdoba (GASCO). Córdoba, El Almendro, 2000.

Diccionario Manual Vox Griego clásico - español. Prólogo de J.M. Pabón. 18." edición. 19." reimpresión. Barcelona, Biblograf, 2000.

Guzmán Guerra, A.; Tejada Caller, P.: ¿Cómo estudiar filología? Madrid, Alianza, 2000.

Hoyo CALleja, J. DEL: «Filología clásica: ¿disciplina en crisis?», EClás.117, 2000, 117-140.

IRMER, D.: «Los estudios hipocráticos en el Thesaurus de Hamburgo: el Thesaurus Linguae Graecae Hamburgensis», Tempus 25, 2000, 5-28.

ISO-ECHEGOYEN, J.J.: “Más sobre las humanidades y menos sobre la cultura de la imagen», Cal.Ren. 1, 2000, 151-154.

JuANes Prieto, J.I.: «Recursos clásicos en Intemet», Capsa 1, 2000, 23-34.

LOPEZ JIMENO, M.A.: «Nuevos sistemas de almacenamiento y difusión de la informació científica: Internet y el mundo griego", Minerva 14, 2000, 239-264.

Rodríguez ADRADOS, F.: «La semántica en el Diccionario Griego-Español», Actas del Congreso Internacional de Semántica I, 99-110. 
RodRíguez Somolinos, H.: «Publicaciones sobre Filología Griega en España (1998)», Epos 15, 1999, 481-537.

Ruzz Casanova, J.F.: Aproximación a una historia de la traducción en España. Madrid, Cátedra, 2000.

SEYFFERT, O.: Diccionario de mitología griega y romana. Traducción de T. Cutanda. Barcelona, Obelisco, 2000.

\section{DidÁctica}

Alamillo Sanz, A.: «Los amores de Zeus a través de la iconografía», Aspectos didácticos 155-200.

ALBERICH MARINÉ, J.: «Aspectos de la enseñanza del latín y el griego en el Bachillerato», Aspectos didácticos 111-153.

AlCALDE-Diosdado GOMEZ, A.: «La necesidad de renovación didáctica en las lenguas clásicas: una nueva propuesta metodológica», EClás.118, 2000, 95-131.

Alvar EZQuerRa, A.: «Las universidades y la enseñanza de las lenguas clásicas: perspectiva histórica», Actas del X Congreso 1, 69-73.

Bernabe, A.: «Cultura clásica y griego en la universidad», Actas del X Congreso I, 45-49.

Calvelo, M.V.; Lillo, F.: «Un ejemplo de mitología comparada en el aula: los orígenes y el destino del héroe», Capsa 1, 2000, 127-141.

CARMOna MUELA, J.: Iconografía clásica. Guía básica para estudiantes. Madrid, Istmo, 2000.

CASASÚS JiménEz, A.: Griego. Iniciación al griego clásico. Bachillerato de Humanidades y Ciencias Sociales. Valencia, Tilde, 2000.

Cerezo Magan, M.: Didáskalos. Método de iniciación al griego antiguo. Lérida, Universidad, 2000.

Escobar Chico, Á.: «Configuración, desarrollo y definición del tópico literario grecolatino», Aspectos didácticos 65-110.

Fernández Garcia, A.J.: «El estudio de la Mitología Clásica a través de un centro de interés: la descripción del Arca de Cípselo» Capsa 1, 2000, 57-76.

GaRCta Fernández, J.: «El libro de texto en la enseñanza del griego y latín. Consideraciones teóricas, enfoques y propuestas para el futuro", Actas del X Congreso I, 51-53.

Gómez Espelosín, F.J.; GuZmán Guerra, A.: Griego 1. Madrid, SM, 2000.

Gómez EsPelosín, F.J.; GuZMÁn GuerRA, A.: Griego 1. Recursos didácticos. Madrid, SM, 2000.

GUANTER Blat, C. ET AlI: Cultura clásica 1. Optativas ESO. Madrid, Almadraba, 2000.

Guanter Blat, C. et Alil: Cultura clásica 1. Optativas ESO. Guía didáctica. Madrid, Almadraba, 2000. 
Graves, R.: Dioses y héroes de la antigua Grecia. Traducción de L. Graves. Barcelona, Lumen, 2000.

HINOJO ANDRÉs, G.: «Las universidades y la enseñanza de las lenguas clásicas: perspectica histórica. Las universidades de Hispanoamérica», Actas del X Congreso I, 75-81.

Homero: La Ilíada. Adaptación de R. Conde Obregón. Madrid, Rialp, 2000.

LORENZO, $\mathrm{J}$.: «Las lenguas clásicas en el Bachillerato y en la prueba de acceso a la universidad", Actas del X Congreso I, 55-57.

Mascaró PONS, J.: «Humanidades y ciencias humanas», Aspectos didácticos 9-39.

MoRales OTAL, C.: «La enseñanza del griego en el Bachillerato», Actas del X Congreso I, 59-65.

Navarrete Orcera, A.R.: «La Cultura Clásica a través de imágenes», Capsa 1, 2000, 35-54.

Navarrete Orcera, A.R.: «Crónicas mitológicas», Capsa 1, 2000, 93-1 10.

Ortiz RuIZ, M.L.: «La Atenas de Pericles como experiencia interdisciplinar», Capsa $1,2000,111-126$.

Piñeiro BermuY, J.: «Didáctica de las Humanidades Clásicas», Actas del X Congreso $1,41-43$.

PUIG, J.J.: Así se descubre la mitología Griega y Romana. Barcelona, Cims 97, 2000.

SChwaB, G.; Domínguez, Á.; Prada, J.M. DE: Dioses y héroes de la Grecia antigua. Traducción de F. Payarols. Barcelona, Juventud, 2000.

Valcárcel Rubio, C.: Griego 1. Bachillerato. Humanidades y Ciencias Sociales. Madrid, Edelvives, 2000.

ValCárCel Rubio, C.: Griego 1. Bachillerato. Humanidades y Ciencias Sociales. Libro del profesor Madrid, Edelvives, 2000. 